\title{
Is Peking Man Still Our Ancestor?-Race and National Lineage
}

\section{From the "Sacred Flame" to "Thank You, Our Ancestor!"}

In a culture known for its emphasis on the veneration of ancestry and family lineage, it is natural for a powerful nationalism to find a descent as ancient as its textual and material cultures can trace, often measured in several thousands of years. However, in China such an ancestral root is found in lithic age fossils and the remains of prehistorical human activities, and is aged at somewhere between two million years at most and seven hundred thousand years at least. The latter has been officially established and represented by Peking Man, a Homo erectus ( $H$. erectus) group who lived in mountain caves of the Zhoukoudian region, about fifty kilometers southwest of today's metropolitan Beijing. First discovered in 1929 when a skull was unearthed, Peking Man, whose archeological sites were found in China, was considered to represent all Paleolithic hominid groups as the direct ancestor of the Chinese people. At the time of the discovery, Peking Man pushed back the timeline for studies of human evolution about half a million years from Neanderthals and put China at the forefront of the field. The most 
recent estimate of the age of Peking Man is seven hundred and seventy thousand years (Shen et al. 2009).

Peking Man's eminence as the national ancestor in contemporary China was first marked by the inclusion of Zhoukoudian on the list of the "One Hundred National Bases for Patriotic Education" by the Department of Propaganda of the CCP Central Committee (DPCCP) in 1997 (Zhongguo gongchandang xinwen 1997), the year of a significant boom in nationalist rhetoric as Hong Kong returned to China after one and a half centuries of British rule. Before, Zhoukoudian was a National Site for Historical Preservation, established by China's State Council in 1962. Since the mid-1990s, however, Peking Man has walked out of the museum and history textbooks to assume a role in patriotic mobilization.

Today, Peking Man's physical presence in Chinese nationalism can be seen in the China Centennial Monument (中华世纪坛) on West Chang'an Avenue in the center of Beijing. The monument has stood since January 2000 to mark the start of "the Chinese century" and to witness "the great revival of Zhonghua minzu." The monument complex includes a sunken plaza with an eternal fire burning at its center called the Altar of the Sacred Flame. The flame was obtained through wood drilling in the caves of Zhoukoudian on the last day of the century, by actors dressed in cavemen costumes and was passed on to $\mathrm{Li}$ Ning, a gymnast with numerous medals for China, and then carried to the monument site through a fifty-kilometer relay. Hours later, at the eve of the new century, Jiang Zemin, the then leader of the party-state, introduced the flame to the altar to consummate the state ritual that has established of Peking Man's symbolism as a perennial sign (CCTV 2000.1).

As a matter of fact, fire obtained from the Zhoukoudian caves through wood drilling has resulted in the use of sacred flames to initiate public events since the 1990s, and has indicated the significance of the work of senior China-originated Chinese (COC) anthropologists to Chinese nationalism. The torch of the Seventh National Olympics (1993) was lit there by Jia Lanpo, a legendary anthropologist who discovered three Peking Man skulls in 1936. Named The Flame 
of Civilization, the torch was relayed to Tiananmen Square, where a massive rally was awaiting. In July 2005, to celebrate the commencement of a cultural plaza in Beijing designed for the 2008 Olympics, Liu Dongsheng (1917-2008), also a senior anthropologist, lit the torch by the same method and passed it on to actors who were half-naked, covering their lower bodies with tree leaves and animal furs, to start a relay with the torch being carried by cultural and athletic celebrities. Photos of the ceremonial fire making in the cave is still displayed online (People's Daily, March 27, 2008). Upon its arrival at the plaza, the director of the State Bureau of Cultural Relics, along with Beijing's deputy mayor, took over the torch to ignite "the Altar of the Sacred Flame and restart the fire of human civilization." When China hosted the 2008 summer Olympics, the route of the Olympic torch in the Beijing area began in Zhoukoudian, where a mass rally over the whole day was organized with various patriotically themed activities. Online photos show that the ceremonial relay started at the site of Peking Man's bronze head statue which projects facial features of the national ancestor. Feng Gong, the torch bearer and a very popular actor, was proudly holding the torch high and was escorted by a bodyguard. The same bodyguards also appeared on the torch's global multi-city relay in the same year to fend off various groups of people protesting Beijing's hosting of the Olympics (People's Daily, August 8, 2008).

Since the discovery of the fossils, Chinese anthropologists have interpreted ash-like remains at the site as evidence of Peking Man's capability with fire, which was believed to be the earliest among the world's primitive hominids. This hypothesis transformed itself into a national pride and the popular perception that ascribes the use of fire to the creation of not only Chinese but also global civilizations. The general reader often takes it for granted that fire was created by wood drilling, unaware of the fact that fire lit by accidental lightening had long preceded fire obtained by artificial methods. As early as the 1930s, under a Nationalist government, a popular narrative of the national ancestry myth titled "From Prehistoric Human to the Chinese" had already claimed that "We pioneered in human evolution and made human civilization bloom. Our ancestor lit up the fire so we could be illuminated. How can the Chinese today not be awakened and inspired!" (Yen 2015, p. 614). Half a century 
later, the CCP's official narrative regarding Peking Man's use of fire went from strong nationalist pride to a claim of international acknowledgement of China's leading role in world civilizations: "Making and using fire was the glorious first attempt in the history of mankind to control nature... The Chinese nation has never given up its unyielding struggle for survival and pursuit for proliferation [and] the fire for hope has never extinguished. ... This spirit will inspire China in the new century and the new millennium to ensure the great revival of the Chinese nation" (CCTV 2000.2). Historical tourism proclaims, "[w]e can say without any exaggeration that the fire in Zhoukoudian illuminated the world" (Wenweipo Daily 2011). International archaeologists' disagreement with the Chinese interpretation of the ash-based evidence is often perceived as a challenge to China from the West, as media report suggests (Yang 2015). The fire lit by Peking Man is also treated on the first pages of history textbooks and highlighted in exercises and exams (Ye 2012; Qu 2013), often along with a map of the distribution of primitive hominids all over China. A history teacher shared with his colleagues his didactic instruction methods that stretch the patrilineal imaginations of students into an unmeasurable past: "You ask them: 'How old are you?' 'How old is your father?' 'How old is your grandfather?' And so on. As students answer these questions, you help them calculate ' 100 years, 1000 years, 10,000 years, 400,000 or 500,000 years and one million years', and so on to establish basic concepts of the long history of our fatherland" (Wei 1984, p. 46).

In history education and nationalist discourse, such a veneration of a lithic-age national ancestor is induced with words describing the positive traits of today's Chinese people such as diligence, brightness, and bravery. Popular culture digs deeper underneath the sundry facts of chronology and relics to attribute the assumed longevity of the Chinese people and civilization to virtues of their ancestors, reflected in a drama titled Primitive Love of Peking Man. As a music, dance, and epic drama, a genre usually reserved for programs of political significance, it pays tribute to Gen (根 “root”), the protagonist whose single-character name indicates his ancestral status. A patriarch of a Peking Man group, Gen's valor and shrewdness are key to the survival of the small family group, 
but his privileged status in the competition for females causes grievance from the young cavemen. As he grows older, he realizes that he can no longer produce healthy offspring to carry on the lineage, so he allows his young rivals to share his female companions. In the finale he throws himself into a bone fire to let others consume his barbequed flesh in a desperate food shortage created by a harsh winter. "Thank you, our ancestor!"- the drama's poster highlights the fact that the virtue of altruism for the survival of the collective has been part of Chineseness since the very beginning of the race (CRJ Online 2010).

The drama incorporated popular culture and the COC theory. A collaboration between the Zhoukoudian Museum and a group of avantgarde artists (Beijing 1998 International Youth Art Troupe), the drama was created to promote the Museum to tourists. To maximize box office proceeds, the drama's poster warned the audience about the content inappropriate for young adults and children, by alluding to violent and sexually explicit scenes legitimate in the context of primitive and promiscuous cavemen life. However, by the end of the drama, in the flame of sacrifice, all sensual scenarios and expectations are sublimated to a tribute to an ancestral hero's altruism. The fire lit by Peking Man thus not only reflects an overarching theme of Chinese nationalism-an anxiety for the survival of the nation and a call for sacrificial patriotismbut also dramatizes the argument made by anthropologists in their debate with geneticists: fire making technology likely enabled Peking Man's descendants to survive the Ice Age while their counterparts elsewhere went extinct, as we will discuss later.

Paradoxically, since the 1960s there have been substantial findings of $H$. erectus fossils significantly predating Peking Man, for example Yuanmou Man (in Chuxiong Yi ethnic autonomous prefecture, Yunnan Province, which is about 1.7 million years old) and Lantian Man (in Shaanxi Province, at about 1.15 million years old). Found in recent years, Jianshi Man (in Enshi Tu and Miao ethnic autonomous prefectures, Hubei Province) is believed to be more than two million years old. However, Peking Man and Zhoukoudian still stand to represent the earliest Chinese people and the earliest Chinese civilization. Historically and institutionally more established in Chinese archaeological and anthropological experience, Peking Man's name also implies 
unique values that could foil any challenges from geographically remote and culturally marginal candidates. Scientific facts yield to ideological preferences for an iconic unifying role in nationalist memorial. ${ }^{1}$

\section{An Ongoing Debate on Peking Man and Chinese Racial Nationalism}

The relationship between Peking Man and Chinese nationalism is a relatively marginal subject in the international China studies community and has only entered scholarly discussions since the turn of the century. There has been only one book on Peking Man in PRC's political socialization which includes discussions on nationalism, and there have been several articles focusing on nationalist, ethnic, or even racial aspects of Chinese discussions on $H$. erectus and they are more relevant to the subject of this book. In this chapter, this literature is outlined and analyzed around the key issue of to what extent the Chinese discussion has enhanced racial discourse in Chinese nationalism.

In 2001, The Journal of Asian Studies published an article titled "Peking Man and the Politics of Paleoanthropological Nationalism in China" by Barry Sautman. It attempted to divert scholarly attentions on Chinese nationalism in post-Mao China from the focus on "'high politics' or the foreign policy of party-state elites" to more cultural and social trends by examining a state-sponsored discourse that adapted a body of complex scholarship of both the archeology and the anthropology of the Stone Age to identify the Chineseness personified by Peking Man. Sautman's research played a pioneering role in the

\footnotetext{
${ }^{1}$ Unlike the names of other famous sites of primitive human habitats, such as Neanderthal and Cro-Magnon, or those found in China, which derive from the names of the immediate localities of the discovery, Davidson Black, a Canadian anatomist and physical anthropologist who supervised and authenticated the discovery in 1929, named the fossils Sina anthropuspekinensis, popularly known as Peking Man, despite the fact that the site is about fifty kilometres from metropolitan Peking. The name was literarily translated into Chinese as "Beijing People." Had it been named "Zhoukoudian Man," or even "Longguo Hill Man" (Longguo Hill, meaning "hill of dragon bones," and which was the name of the immediate site where Peking Man fossils were discovered), it perhaps would have sounded less magical to Chinese nationalism.
} 
discussion by establishing some key arguments and analytical concepts. He agreed with some scholars' preliminary observation that in a time of racial nationalism's retreat in most major states, Chinese nationalism had shown more "official efflorescence" expressed in the concept of blood ties. As he stated: "Official PRC paleoanthropology undergirds a Chinese patriotism that resonates with a folk taxonomy that understands 'race' as an evident, natural, fundamental, pervasive, omni-historical, and biologically significant division of the world's people." The so-called "politics of paleoanthropological nationalism" was its manifestation. Sautman defined this politics of paleoanthropological nationalism in the Chinese rejection of the internationally accepted Out-of-Africa theory regarding the monogenetic origin of modern humans by insisting on a polygenetic origin to support an independent progenitor of $H$. sapiens in China. Behind this nationalist assertion of a native origin was a bolder "Sinocentric evolutionary theory" held by some Chinese scholars. Sautman's data were mainly drawn from scholarly discussions, media reports, and talks by high-ranking leaders'. Sautman convincingly revealed a strong consciousness among Chinese scholars of the political sensitivity attached to the discussion on fossils, and he dialectically portrayed the nationalist Peking Man narrative as "a kind of reverse teleology, in which the present-day nation is projected as the inevitable consequence of evolution" (Sautman 2001, p. 104). For Sautman, this Chinese discourse was a pronounced case of racial nationalism, which "holds that each of us can trace our identities to a discreet community of biology and culture whose 'essence' has been maintained through time" (Sautman 2001, p. 95).

The key point in understanding this seemingly esoteric discussion involves a debate between the world's mainstream paleoanthropologists and their Chinese peers. While the former adopt the theory first proposed by Allen Wilson and Rebecca Cann in their famous 1987 collaboration "Mitochondrial DNA and Human Evolution" and believe that both $H$. erectus and $H$. sapiens originated in Africa, that modern humans are the descendants of the $H$. sapiens who migrated out of Africa as early as one hundred and twenty-five thousand years and as late as sixty thousand years ago and replaced the previous $H$. erectus groups worldwide, the latter claims that the $H$. erectus group that had arrived in the land 
of what is today's China had independently evolved into H. sapiens. Ordinary readers may construe the meaning of the debate simply as a question regarding whether the Chinese share a common modern human origin with the rest of the world, and if not, then exactly how old are they-one million or two million years?

Sigrid Schmalzer's 2008 book, People's Peking Man: Popular Science and Human Identity in Twentieth Century China, is a comprehensive study of the role of Peking Man in the PRC's ideological indoctrination and political socialization against a backdrop of how modern states have used scientific education to shape citizenship. Such a political agenda in the PRC established a human identity free from the influence of the Christian creation myth and folk religious superstitions regarding the origin and evolution of mankind, and helped to promote socialist ethics that exalted physical work by using Peking Man-believed to have been able to use tools - as an example of what Frederick Engels argued in his The Part Played by Labor in the Transition from Ape to Human. This official effort in popular science to some extent led Schmalzer to arrive at the conclusion that it was in the early years of the PRC that Peking Man's status as the national ancestor was officially established, despite the fact that prior to 1949 some propagandists of the Nationalist regime had ventured to do so out of nationalist political agenda. However, she agreed with Sautman that "a nationalist state agenda has worked to privilege scientific theories that root Chinese ethnic identity in the remote past," which emphasized "the longevity of the Chinese as a biological race and the connection of this race to the Chinese land." She also agreed that such a trend had accelerated from the 1980s.

However, Schmalzer disagreed with Sautman on the extent that such an ethnic identity politics had played in the Chinese emphasis on Peking Man. First, as she argued, the Chinese discussion was also a scientific (and not merely political) debate, since "the jury is still out on many questions about human evolution," and the Chinese scientific community-archeologists and paleoanthropologists-is in general open minded towards the debate regarding the foreign or native origin of their ancestor. Second, even in the political motive, a claim for China's central role in the origin of humans- "a question more of prestige in international science"-was more prominent than ethnic 
identity. Third, the construction of "a concept of a biological race" is "simultaneously destabilized by other meanings produced by scientists, laypeople, and the state itself." Finally, many individual Chinese regard human fossils such as Peking Man "not simply as early representatives of their nation or race," but also as "family, community, regional, professional, and human identities" (Schmalzer 2008, pp. 248-250).

Thus both Sautman and Schmalzer agreed upon a nationalist agenda behind the Chinese discussion on Peking Man, but differed in their assessments of how political the discussion was and whether a racial nationalism characterized such a discourse. In tracing the construct of the discourse of a historical China in lineage and space to define and defend China as a legitimate nation state against the odds of a historical complex of changing and often ambiguous territorial and ethnic lines, James Leibold engages Peking Man in his articles "Competing Narratives of Racial Unity in Republican China: From the Yellow Emperor to Peking Man" (2006, "Competing Narrative" hereafter) and "Filling in the Nation: The Spatial Trajectory of Prehistoric Archaeology in Twentieth-Century China" (2012, "Filling in the Nation" hereafter). They involve the late Qing dynasty and the PRC, but focus on the Nationalist era, a time critical to the transition from a multi-ethnic empire to a modern nation state. This transition was notably disrupted by Japan's encroachment and invasions in the 1930s, which made Peking Man a timely and meaningful discovery for Chinese nationalism. Leibold's interpretation gets more to a reading of a racial national identity that Peking Man was appropriated to establish.

In "Competing Narratives," Leibold reveals the tension between a shared consciousness of a homogenous "Chinese nation"-a "racial unity"-and different narrative approaches to this consent among leading Chinese intellectuals whose lifetime crossed the Nationalist and Communist regimes. Facing a rather messy history of heterogeneous ethnic and racial components as well as the power relations among them that could lead them to see each other as the Other, Chinese scholars in the early twentieth century worked strenuously to seek "scientific proof of this unitary national imaginary." While one narrative identifies the source of such unity in the common origin for all members of the Chinese nation, the other describes the nation as a result of a 
gradual and evolutionary "melting" of the whole. While both imagined the Chinese nation of the time as a community of common consanguinity, the common origin discourse took the ancestors of the Han people as the springboard of such a community, explicitly identifying the Yellow Emperor (along with some other sage kings praised in Han folklore) first and Peking Man later as the ancestor of the entire Chinese nation.

The discovery of Peking Man came in the nick of time when Gu Jiegang, a famous historian, exposed and critically analyzed the lack of sufficient and verifiable evidence in Chinese historical records to demystify national origin narratives constructed since the late Qing era that were based on a single progenitor and a homogenous racial family. Gu and his followers were thus called "doubters of antiquity." "The government does not have to lie, telling us that we have descended from the same ancestor," such was Gu's political denunciation of the officially endorsed national origin myth in the late 1920s. Gu argued for a theory that recognized the multiple ethnic and racial origins of the Chinese nation, and he believed that such a theory not only reflected historical truth but also would not hurt the shared consciousness of a unified Chinese nation. On the contrary it honored contributions to the formation of the nation made by non-Han peoples, and would therefore help national unity.

After the discovery of Peking Man, while some scholars were cautious to accept his ancestor status for various reasons (some were waiting for further scientific verification, and others found Peking Man's facial features looked like those of black slaves rather than sagacious ancestors), more enthusiastic nationalist intellectuals, some associated with the Nationalist Government, believed that the discovery "provided scientific evidence of the autochthonous provenance of the Chinese people." Gu's "doubting of antiquity" and his theory of a Chinese nation with polytheistic components now seemed to be losing ground. The most adamant and confident advocate for Peking Man's ancestorship was Xiong Shili, a very influential cultural conservative and neo-Confucian philosopher, who held a series of lectures on Chinese history at the Central Military Academy in 1939. Xiong told his audience that "[a]mong the descendants of Peking Man, one branch remained in the Divine Land 
[神州, meaning China] and became today's Han lineage," while the others spread in all directions and became the ancestors of the principle non-Han minorities (Leibold 2006, pp. 203-205).

In "Filling in the Nation," Leibold applies the concept of "geo-body," a biological nationhood imagined through mapping out the sites of prehistorical human remains and activities (a typical example involves the maps of such sites and illustrations that appear in the beginning of history textbooks in China), to foreground the spatial rather than the temporal significance of Peking Man to Chinese nationalism. Since the process of nation-state making demands the inclusion and binding of all ethnic and racial groups within the national borders, an antiquarianism of such border formation values Peking Man and other primitive humans found in China today as the most undeniable evidence of the existence of a historical China that has continued through a bloodline originated from those lithic-era sites. In the 1930s and 1940s, many Chinese nationalist scholars had suggested that Peking Man was the common progenitor of all the peoples in China. By the time of the early PRC, as Leibold believes, the need for defining borders and uniting different ethnic groups became more urgent as well as realistic under a centralized nation state, and "Peking Man was now clearly positioned as the direct, linear ancestor of $H$. sapiens, the yellow race, and the zhonghua minzu (中华民族 Chinese nation)" (Leibold 2012, p. 346). Therefore, from different perspectives, both Schmalzer and Leibold reached the same conclusion regarding the time at which Peking Man was officially enshrined as the national ancestor.

The relationship between Peking Man and Chinese nationalism has also been examined from the perspective of a paradigm shift in the exploration of human origin from Asiancentrism to Sinocentrism after Peking Man's discovery. In her article "Evolutionary Asiancentrism, Peking Man, and the Origins of Sinocentric Ethno-Nationalism" that covers the period between the 1920s and the 1940s, Hsiao-Pei Yen extended the discussion to emphasize the "invention" of Peking Man's national ancestor status as the result of "negotiations between scientific universalism (or internationalism) and nationalist commitments" (Yen 2015, p. 591). The discovery and authentication of Peking Man fossils, according to Yen, was due to many foreign anthropologists' hopes and 
efforts in finding a human ancestor of lithic age in Asia, especially in what is today's north and west China. The driving force of this paradigm shift was the discovery of more early hominid evidence in Asia and had nothing to do with Chinese nationalism, but its result was read and exploited by the latter which helped to construct a national identity with racial implications. As a matter of fact, since that time, the negotiations between scientific cosmopolitanism and its nationalist appropriation have continued to characterize academic and popular discussions regarding Peking Man.

The above discussions have introduced Peking Man's significancean otherwise purely scientific subject-into our consciousness about Chinese nationalism by establishing an analytical framework that identifies its political and ideological implications against historical contexts. It also extracts and expresses in common language some key concepts from voluminous highly specialized hypotheses, theories, and knowledge, to make sense of the debate for ordinary readers. All authors agree that the Chinese discussions about Peking Man-and more broadly, paleoanthropology and prehistorical archaeology—serve a nationalist agenda with its racial implications. However, there is not only a divergence regarding the significance of such a racial aspect in the nationalism, but also and more importantly a lack of a theoretical explanation as to why the discourse is racial, although simply by creating and applying those concepts a reader informed by fundamental knowledge about racial thinking can clearly see the association between them. This theoretical elaboration is necessary not only because it will effectively engage the Chinese defence that has rejected even nationalist-let alone racial-implications of the discourse, but also because it will contribute to our understanding of the varieties of scientific racism that appear to have nothing to do with a harmful or even dangerous racist agenda.

This chapter therefore furthers the discussion in the hope of addressing these issues and remedying these deficiencies, based on important developments either not examined in the previous literature or which have arisen since. First, it emphasizes that since the 1990s, Peking Man's assumed ancestorship of the Chinese people has been further valorized as a symbol in state-sanctioned patriotic mobilization, instead of a mainly paleoanthropological interpretation in nationalist discourse. 
Evidence points to a deep-seated consciousness existing even among the top leaders of the Chinese being the most evolutionarily advanced human species among the world's populations. Second, it focuses on Chinese discussions on genetic challenges to this ancestorship and sets the challenge in the historical context of China's participation in the international Human Genome Project (HGP) in the late 1990s and early 2000s to give an understanding of the provocation of the debate as well as the actions taken by the Chinese state and scientific community. Third, while acknowledging the archeological ground for the China-origin Chinese (COC) theory, the chapter nonetheless reveals in detail the academic debate between the two theories regarding the origin of people. While geneticists in general hold a belief in Africaoriginated Chinese (AOC), anthropologists continue to defend the COC theory. The debate has carried and enhanced political sensitivity as a result of the discourse strategies employed. In other words, the issue is scientific (there is indeed archeological evidence in favor of the COC theory), but the way it is addressed in many situations reads in a political way. Fourth, the chapter shows how lay supporters of both the AOC and COC theories fully understand the nationalist implications immersed in such a professional debate and have engaged each other in a public discussion through various media channels. This new phenomenon reflects the sociopolitical impact of scientific debates in a time of mass media and social media, and is analyzed in light of a broader national ideological divide between ultranationalists and liberal-oriented groups. Chinese society's more diverse attitude towards Peking Man, as Schmalzer emphasized, now includes a potent internationalist antidote to the nationalist stimulant.

This chapter thus argues that, galvanized by the challenge from genetics to the persistent veneration of Peking Man as the national ancestor, the Chinese discussions - both academic and popular-on the subject have revealed the more political and especially racial meanings of the issue. The fact that society scientifically accepts the AOC theory cannot obscure the fact that the COC theory still serves the nationalist agenda. On the contrary, the coexistence of the two facts only enhances the tension within Chinese nationalist politics, and forces COC advocates to seek a more effective discourse strategy that often appeals 
to concepts and terminologies that are more racialized or simply racist when judged by international standards. Inspired by international studies of similar discourses dubbed such as $H$. europaeus, $H$. alpinus, and $H$. israelensis, which constructed various imagined ancestors who bequeathed essentialized communal traits to their posterity, this Chinese discourse can be called " $H$. sinensis," with a much more prehistoric and therefore biological root to it. Mystifying its association with the land, this $H$. sinensis collaborates with the rising racial nationalism expressed in pop music introduced and analyzed in the previous chapter, which epitomizes Chineseness with explicit racial taxonomies. Further, it advances this nationalism by elevating Chinese civilization among the world's civilizations with a claim for an incontestably greatest antiquity, and creating a most cohesive force for nationalist mobilization by establishing a common bloodline.

\section{AOC or COC?-A Debate Between Geneticists and Anthropologists}

Peking Man's recent prominence reiterates what Chinese nationalism had assigned to it before. It has risen in defiance of a cutting-edge scientific challenge in the context of China's participation in the Human Genome Project (HGP) that enhanced the debate between geneticists and anthropologists with public repercussions. The HGP was launched in 1990 by the United States and comprised four developed nations. By decoding and mapping all the genes in the human genome, this postCold War global collaboration had an immense impact on the determination and preservation of human genetic distinction and diversity, therefore its results can also be read as "a history book-a narrative of the journey of our species through time" (National Human Genome Research Institute 2012). This "history book" opens with a single African-origin H. sapiens as the ancestor of all modern humans and goes on to provide genetic interpretations (including migration and interbreeding, among other factors) for the racial and ethnic differences of all peoples in the world. 
Despite the obvious scientific benefits that the HGP created, sharing national genetic data within the program raised concerns in the participating countries. ${ }^{2}$ Weighing the benefits against the risk, the Chinese state decided to join the HGP in 1993 and officially made its entry in 1998 after five years of preparation, becoming the only developing nation in the project. The National Natural Science Foundation of China (NNSFC), under China's State Council, funded "Research on the Human Genome in China," and established a southern center in the State Key Laboratory of Genetic Engineering in the Institute of Genetics, School of Life Sciences, at Fudan University in Shanghai. A northern center was also established in the Human Genome Center at the Chinese Academy of Sciences in Beijing. This national scientific endeavor started with a project titled "Research on Some Structures of Gene Loci in the Genome of Chinese People," which resulted in a contribution to the global genomic map (Jin and Chu 2006, p. 2). This participation has been reviewed as a strategic development in promoting China's national interest- "The Battle for Genetic Resources is as Important as a Battle for Territory," as the title of an interview with the director of HGP’s Beijing project clearly indicated (Ji 2007).

\footnotetext{
${ }^{2}$ Major political concerns include how to treat DNA data as a new form of national property and security. Paul Rabinow illustrates a dramatic case in this regard with the French government prohibiting French scientists from offering "French DNA" to Millennium, a HGP-related US biochemical company in 1994 (Rabinow 1999). In China, concerns and debates emerged over possible gene outflow to the West and even alleged gene weapons particularly devised to sap the Chinese nation. Titles of reports in national media included "To Protect Our National Security, Safeguard Our Genetic Code" (China Chanjin xinwen bao 2002) and "Is the Chinese Nation's Gene Safe? Are Our DNA Samples Outflowing?” (People's Daily 2005). Chinese geneticists explained that what they shared with foreigners were not samples of saliva or blood but just certain categories of selected data drawn from these samples. However, this concern still persists and is dramatized in popular culture. A recent movie titled War Wolf (战狼1) includes scenrio of international genetic weapons developers using stolen "Chinese DNA" to make biochemical weapons to attack China. The movie can be seen as a political interpretation of discussions on a Harvard-based Chinese-American biologist's collection of gene samples in China in the late 1990s and early 2000s for his research on chronic diseases also funded by the National Institute of Health, USA, and also associated with Millennium. Chinese scientists and media later became alerted by the scientist's research conduct for ethical and legal reasons, which prompted a government investigation in the United States (Harvard School of Public Health 2003).
} 
What led this Chinese participation to call Peking Man's ancestorship into question were the research activities conducted by a group of Chinese scholars affiliated in various ways with American institutions. Key to this affiliation was Tan Jiazhen, a founding figure of Chinese genetics who studied at Caltech in the 1930s with Thomas Hunt Morgan, the father of modern genetics. In the 1950s, after returning to China, Tan resisted Soviet criticism of genetics—especially Morgan's theory-as Western bourgeois science and strove for the survival of the science in China. ${ }^{3}$ He urged the Chinese state to join the HGP in the 1990 s by using his contacts among Chinese leaders, ${ }^{4}$ and succeeded in getting Fudan-his home institution-to become the southern center for China's genomic research. He also helped to connect China's young geneticists to the international scientific community. Among those scholars, the most important figures include Jin Li, a geneticist trained in the United States and a research scientist at the Human Genetics Center, University of Texas-Houston (HGUT) in the late 1990s; Chu Jiayou, from the Institute of Medical Biology, Chinese Academy of Medical Science, who was also a visiting scholar in the United States in the 1990s; and Su Bin, a postdoctoral fellow at HGUT in the late 1990s. Their international connections made them more aware of the relationship between the Out-of-Africa theory and the HGP, and they also knew that the data supporting that theory did not cover China. ${ }^{5}$ Intrigued by the contradiction between this international mainstream science and their nationalist belief, they saw Chinese participation as an opportunity to test both.

\footnotetext{
${ }^{3}$ The Soviet criticism of genetics was based on Lysenkoism, an officially endorsed pseudoscientific theory under Stalin that only recognized acquired characteristics but rejected inherited ones in relation to biological evolution.

${ }^{4}$ As an internationally known scientist, Tan was selected in the 1990 s by the CCP leadership to be Honorary Chairman of the China Democratic League, the largest among eight democratic parties that function as the CCP's consultative partners, especially among intellectuals. Tan used his influence to secure China's partnership with the Human Genome Project (HGP) by directly addressing its strategic importance to Jiang Zemin (Zhang 2013).

${ }^{5}$ In 1995, Japanese geneticists provided mitochondrial DNA evidence collected from Japanese people to support the Out-of-Africa theory (Horai et al. 1995).
} 
The data these Chinese geneticists collected in China completely supported the Out-of-Africa theory. Starting in 1998, they began to publish in international scientific periodicals such as Proceedings of the National Academy of Sciences (PNAS), The American Journal of Human Genetics, Human Genetics, and Science. The first report, "Genetic Relationships of a Population in China," analyzed the microsatellite data of twenty-eight mostly non-Han minority population groups in China (a microsatellite is a type of molecular marker used to determine kinship or genetic relations). It concluded that the "genetic evidence does not support an independent origin of Homo sapiens in China" (Chu et al. 1998, p. 11763). A more important report was published in Science in May 2001. Titled "African Origin of Modern Humans in East Asia: A Tale of 12,000 Y Chromosomes," the project used chromosomes as a more accurate data indicator and expanded a sample poll to include Han Chinese (4592 and 5127 samples from northern and southern Han Chinese, respectively) and other ethnic groups in East Asia. By identifying a genome mutation carried only by males "which originated in Africa about 35,000 to 89,000 years ago" but found in all individual samples, the report rejected even a minimal likelihood of a native origin of modern humans from East Asia (Ke et al. 2001, p. 1151).

The first report was originally submitted to Science, but the editor decided to wait due to concerns over the significance of the subject. Tan Jiazhen then suggested the authors try PNAS (Huang 2008). It was quickly published by that journal and Nature immediately followed up with a lengthy commentary. That was the first time that the international scientific community confirmed the Out-of-Africa theory with data collected in the world's most populous country. When "African Origin of Modern Humans in East Asia: A Tale of 12,000 Y Chromosomes" was submitted to Science three years later, it was quickly accepted. Although the research was conducted mainly by Chinese scientists organized in or benefiting from NNSFC projects, the results were first announced in international journals and then disseminated back to China through the media. Such a phenomenon is often called "import via export" in China meaning that international recognition helps domestic status. After the 1998 PNAS report made Chinese scientists aware of its challenge to Peking Man's ancestorship, the 2001 
Science report received more publicity in China. The NNSFC official bulletin commented that although fossil and anatomical evidence found in China still suggested the possibility of the COC theory, "we very likely have to accept such a point of view: our ancestors came from Africa" (NNSFCB, February 6, 2002).

A speedy translation and publication of The Journey of Man: A Genetic Odyssey in 2004, only two years after its English edition appeared, joined the challenge in a more popular form. Written by Spencer Wells, the book and a documentary with the same title have been recognized as one of the most influential popular interpretations of the Out-of-Africa hypothesis. The book has very little on China-since discussions on China had only recently emerged-but quotes Jin's work as "bad news" for those who believe in multiregional continuous evolution. The Chinese publisher's inclusion of numerous photos and maps indicates the strong expectation for a broader audience, and its preface alerted that "for Chinese readers, there must be a lot to ponder," because contrary to the theory that "Chinese people evolved from an uninterrupted development of local 'Peking Man' and other $H$. erectus groups, the author finds that there is no evidence for such a hypothesis" (Wells 2004, p. 29).

With further data collection and analysis consistent with these publications in China - a very recent one was announced in 2014 by the Institute of Zoology of Kunming in Yunnan Province (IZKYP) which included six thousand individual samples (IZKYP, August 25, 2014) the AOC theory has enjoyed wide appeal in Chinese society, especially in the natural science community. Branches of the social sciences and humanities have also felt the impact with nationalist and ethnic nationalist implications. One such field is that of linguistics. Quentin Atkinson's hypothesis that the phoneme roots of many native languages can be traced back to Africa-an evolutionary linguistic school inspired by the Out-of-Africa theory-is echoed among Chinese linguists in their search for the origin of the Chinese language (Yao 2010). Ethnography has become more prominent in ethnic studies as molecular anthropology has become more popular, diverting attention from textual and material culture analysis to lab results of population genetic surveys, leading to the reinterpretation of the origin and migration of many ethnic minority peoples and their relations with the Han and the 
Han-dominated state (Jin and Chu 2006, pp. 227-240). One intriguing result is the discussion on the demic-diffusion model of Han expansion in southern China - as opposed to the traditional cultural diffusion model, i.e., Han expansion resulted from non-Han peoples' adoption of more civilized Han culture-which shows a predominant pattern of a DNA mix of Han-males and non-Han females in southern China's Han population. This result was also first published by Nature (Wen et al., September 16, 2004). By interpretation, this could suggest a tantalizing concept of a longue durée internal gender-based colonization.

Molecular anthropology has also added new fuel to the fire of the conflict between mainland and Taiwanese nationalisms within a particular context: the outbreak of SARS in 2002-2003. The attempts by Taiwanese hematologists to analyze the impact of the virus among different population groups in East and Southeast Asia made them aware that both mtDNA and the $\mathrm{Y}$ chromosome of aboriginal Taiwanese are much closer to those of Austronesians rather than those of the mainland Chinese. "We have different blood," a claim made by a leading Taiwanese hematologist in the title of her book thus argues for a much more diverse origin for the Taiwanese and refutes Chinas "same blood, same ancestor" discourse in its nationalist claim over Taiwan (Lim 2010).

The geneticists' challenge to the COC theory, however, met with swift resistance from anthropologists clustered in the Institute of Vertebrate Paleontology and Paleoanthropology (IVPP) at the Chinese Academy of Sciences, the institutional spokesperson for the COC theory. The IVPP was formerly the Research Department of the Cainozoic Era (RDCE) at the Institute of Geological Survey of China in the Chinese Ministry of Agriculture and Commerce, established in 1929, the year of the discovery of the Peking Man fossils. The institute's history was essentially a result of Sino-Euro-American scientific collaboration, ${ }^{6}$ which not only trained the first generation of Chinese

\footnotetext{
${ }^{6}$ The institute was affiliated with Peking Union Medical College (established by The American Board of Commissioners for Foreign Missions), especially its anatomical department, which at the time was the institutional home for physical anthropology. Between 1929 and the outbreak of the Pacific War, European-American scientists assumed responsibilities for the institute's administration, and the Rockefeller Foundation financed the work on the archaeological site.
} 
anthropologists and archaeologists, but also laid the foundations for the COC theory. Franz Weidenreich (1873-1948), an anthropologist at the University of Chicago known for his multiregional hypothesis of human evolution, was honorary director of the RDCF in the mid1930 s and that experience played a role in the formation of his theory. Most COC advocates such as Pei Wenzhong (the discoverer of the first Peking Man skull in 1929), Jia Lanpo, and Yang Zhongjian (coordinator of Zhoukoudian's excavation in the 1930s), were trained on site by Western anthropologists and then became elders in the IVPP. They were even all buried in Zhoukoudian at their request. Official historical narrative elevates their professional careers as patriotic commitment, as elsewhere anthropologists and archaeologists who helped in constructing national history become nationalist heroes. Today, among the IVPP's researchers, Wu Xinzhi, Huang Wanbo, and Gao Xin are ardent defenders of the COC theory.

Contrary to genetic data supporting the AOC theory, Chinese anthropologists have shown rich evidence for a seeming evolutionary continuity in the form of similarities between the morphological, anatomical, and cultural remains of $H$. erectus and $H$. sapiens found in China. Morphological and anatomical evidence include such physical features as a flat-fronted face with projecting cheekbones, shovel-shaped incisors, a low nasal bone, and rectangular-shaped eye sockets. Evidence from cultural remains shows that quartz and sandstone tools fashioned by a chopping action seem dominant from 1.7 million years ago to about thirty thousand years ago, but in Africa and the Middle East (a corridor for the journeys of $H$. erectus and $H$. sapiens "Out-of-Africa"), tool-making technology seems more advanced and obsidian hand axes are commonly found. So the COC argument is that if the AOC theory is true, then why didn't those African-originated $H$. sapiens bring that technology to China (Wu 2006; Gao 2010; Hua Ti 2009.2)? More generally, for COC supporters, a nationwide distribution of thousands of archeological sites of both $H$. erectus and $H$. sapiens makes any scenario of a complete replacement by a single foreign species hard to believe.

Anthropologists responded to the AOC theory in the first media reports of the geneticists' work in summer 2000, in which they were 
interviewed, notably Wu Xinzhi. Wu, the chief opponent of the AOC theory, who used fossil data from East Asia to propose a multiregional evolution model for modern humans with the American Milford $\mathrm{H}$. Wolpoff and the Australian Alan G. Thorne (1939-2012) (Wolpoff et al. 1984). Wu has since maintained that "four main races in the world all linked to a more archaic human species in their respective locations, all native born" (Wu 2003). Wu told the newspaper that fossils were the most direct evidence while DNA was indirect and fragmentary. ${ }^{7}$ As he stated, "Over the last 50 years, Chinese archaeologists have found many sites of paleoanthropological fossils and more than a thousand locations of Paleolithic culture remains. [They show] that there were no discontinuities between $H$. erectus, represented by Peking Man, and the modern Chinese, and [the evolution was] an 'expansion like a river network with small amount of interbreeding'" (Huashengbao, June 15, 2000). Three months later in an article titled "Is Peking Man Still Our Ancestor?" Wu reiterated the possibility of an incidental interbreeding between African-originated and China-evolved $H$. sapiens (Wu 2000). This referred to some anatomical features of $H$. sapiens found in China, such as round-shaped eye sockets and a projecting occipital bone, which appeared more common in Europe (Wu 2003). This revisionist reconciliation with genetics is yet to be supported by critical evidence, although geneticists have recently begun to suggest a similar scenario in regard to Neanderthal Man (Green et al., May 7, 2010; Pääbo 2014). As he was opposed to a phylogenetic tree concept of both $H$. erectus and $H$. sapiens with Africa as the common root, Wu accepted the former but insisted on his "river network [meaning a multiple source of origin] with a small amount of interbreeding" hypothesis for the latter's global evolution. With a multiregional evolution with incidental mixing, rather than a single African-origin mutation and replacement, Wu's model for $H$. sapiens has been the COC's theoretical paradigm.

\footnotetext{
${ }^{7}$ According to Schmalzer who interviewed Wu Xinzhi in 2005, Wu invited Jin Li to the IVPP (time not specified) to exchange opinions but remained unconvinced afterwards (Schmalzer 2008, p. 271).
} 
Responding to anthropologists' defensive arguments, the geneticists have mainly stood the ground of their own discipline with undisputable evidence for the AOC theory. They also call attention to the difficulty in determining the relatedness between two human groups simply by matching facial and skull resemblances, which could be subject to the existing perception of the observers. More importantly, they point to a breakage of archaeological evidence in the assumed evolutionary continuity found in China. This breakage is an absence of evidence of fossils and cultural remains for the time between one hundred thousand years ago and forty thousand years ago, a key stage in which $H$. sapiens (early modern humans) evolved into $H$. sapiens sapiens (the complete modern human). As Jin $\mathrm{Li}$ and others have explained, this breakage is not an accident but was created by the quaternary glacier which caused the extinction of many species globally, and following which a new $H$. sapiens migrated from Africa and spread all over the world (Jin and Chu 2006, pp. 234-235). To this, anthropologists have argued that the climate in some parts of East Asia during the Ice Age was relatively milder and because primitive humans there had been able to make fire, they might well have been able to survive the cold. Therefore the fire made in the Zhoukoudian caves once again set the ancestors of the Chinese apart from their peers elsewhere, a technical plausibility moralized in the drama Primitive Love of Peking Man. Since the debate started, the main task of anthropologists has been to find the missing link evidence that will testify to the survival of Peking Man's descendants throughout the Ice Age.

As the debate was made public, Chinese media's attitude reflected this scientific divide but often sensationalized its nationalist implications. Reports were either titled "Peking Man Is Not Our Ancestor Anymore!" or "Chinese Archeologists Are Once Again Challenging the Universal 'African Origin' of Modern Humans!" However, a more neutral, ambivalent position, often sympathetic to the COC theory but with "a careful agnosticism” (Schmalzer 2008, p. 270), was also common. CCTV's involvement showed such a position with palpable nationalistic sentiment. Responding to international popular media presentations on the AOC theory, CCTV came up with a Chinese version of the story, a five-episode series in 2011 titled Where Did the Chinese Come From? 
The program admitted that the AOC theory was currently the mainstream science but presented the COC theory as a legitimate hypothesis. The episode narrating the debate was titled The Remote Eden. It claims, half jokily, that since international geneticists used mitochondrial DNA (the matrilineal line) to trace human evolution elsewhere, thus known as the "Eve theory," but Chinese geneticists used the $\mathrm{Y}$ chromosome (the patrilineal line), China should still be proud of being "the remote Eden" where an "Adam" has been identified to consummate the evolutionary union.

\section{An Academic Debate with Political Discretion}

This Chinese debate constitutes part of the international discussion on the impact that DNA studies have had on unsettled issues in many fields, especially those related to history and identity (Wailoo et al. 2012). The cleavage between the COC and AOC theories mirrors an international debate between a minority and a majority of anthropologists since the joint work of Wilson and Cann in 1987. The former claims a multiregional origin for $H$. sapiens, as pioneered by Weidenreich and now represented by Milford Wolpoff and Rachel Caspari. These anthropologists are fully aware of the political implications of the discussion, since Wilson and Cann's finding is seen as a scientifically decisive blow to white racism, and call the subject "a public discipline," referring to non-professional interest in the discussion. They feel their academic standing is often mistaken for polygenism by the public, an outdated anthropological theory of the parallel evolution of human races from the genesis that had lent credence to racism in the past. From their perspective, while they are seen to be denying the idea of "all brothers under the skin," their rivals appear to be on the moral high ground of a politically correct ideology of a universal humanity and are therefore rewarded with enormous popularity by an uncritical public, and especially media. A scientific hypothesis cashes in on a popular social agenda (Wolpoff and Caspari 1997, p. 54).

This international anthropological school has been essentially Chinabound, with Weidenreich's theoretical foundation work some eighty 
years ago and a collaboration developed between Western anthropologists and their Chinese colleagues. After a long break under Mao, the relationship quickly resumed with Wolpoff and Thorne's trips to the IVPP in the early 1980s and their meeting with Wu Xinzhi there. They took the findings of remarkably substantial evidence for both $H$. erectus and $H$. sapiens in China in the previous decades as critical evidence for their evolving concept of a multiregional theory. In 1983, Wolpoff invited $\mathrm{Wu}$ to the United States on a National Science Foundation fellowship based in the University of Michigan, Wolpoff's home institution. These exchanges led to their coauthored 1984 article which reinvigorated the multiregional argument. Since Wilson and Cann's findings in 1987, however, their collaboration has been an alliance against the challenge from genetics. The most recent activity of the collaboration is Wolpoff and Caspari's article published in the IVPP's journal in both English and Chinese languages (Wolpoff and Caspari 2013).

Instead of race in the international discussion, ancestor is the key word in the Chinese debate. The political implication in China is about how much "we" are different from the rest of the world, creating a tension between genetic facts and nationalist sentiment. However, the word ancestor is functionally a Chinese equivalent of race, this chapter argues. Chinese geneticists and anthropologists are aware of the political implications of their research for Chinese nationalism, but they refrain from an explicit appeal to such an interpretation. Neither a genetically universal modern human origin nor an anthropological Chinese pedigree is openly used to occupy a moral high ground or claim political correctness. The discussion is not politicized, but a close reading of the discourse on both sides reveals a delicate discretion in a tension concealed under piles of scientific jargon and research statistics.

In general, the geneticists tend to circumvent political sensitivity, leaving the interpretation of their findings open to their audience. Jin $\mathrm{Li}$, the author of most articles or research reports written by Chinese geneticists and published in international journals around 2000 and now a leading scientist at Fudan University, has become a spokesperson for the AOC theory through popular science writings, media interviews, and public lectures and has been recognized as such by his foreign colleagues. Alice Roberts, a British anthropologist who wrote and hosted 
the BBC's four-episode documentary series The Incredible Human Journey, another popular science project in 2009 after The Journey of Man promoting the Out-of-Africa thesis in which China is well represented, interviewed Jin in his lab. With an Out-of-Africa view, Roberts disagreed with Wu Xinzhi in another interview in Beijing for the documentary. Roberts appreciated Wu's kindness in receiving her in the IVPP and showing her skull fossils of Peking Man. To Wu's interpretation of similar morphological features between the skull and modern human, however, Roberts not only remained unconvinced but told Wu that such similarities seemed "subtle" to her. Roberts finds an ally in Jin's lab in Shanghai. Jin's remarks show that he is conscious of the implications of his research for Chinese nationalism, and he seemed delighted about the common origin of Chinese and other modern humans,

Before the project [i.e., the project leading to the 2001 Science report] started, I was hoping that I could identify or would be able to find evidence to support an independent origin of the Chinese in China, because I am Chinese, I came from China, and through the educational process I always believed there was something special about Chinese." [To Roberts' question "How did you feel as a Chinese person?" Jin answered] "After I saw the evidence generated in my laboratory, I think we should all be happy with that, because, after all, modern humans from different parts of the world are not too different from each other and we are all very close relatives. (Roberts, BBC 2009)

However, when facing domestic media, Jin sounds more neutral. When interviewed by CCTV's program Where did the Chinese come from?, Jin only emphasizes his initial doubt about the validity of the Outof-Africa theory for the origin of the Chinese and his hope for a kind of "different result" from the data to be collected in China (CCTV 2011). ${ }^{8}$ In his other public talks, he rarely makes any reference to a Chinese identity to which Peking Man is attributed, despite his staunch position on

\footnotetext{
${ }^{8} \mathrm{Chu}$ Jiayou also admitted his hope of finding a "non-African, independent Chinese gene" before he started his research that resulted in the 1998 PNAS report (Huang 2008).
} 
the validity of his team's findings in answer to the question "from where did we come?" (Jin 2005). He never asks the public and the state to reconsider the popular veneration of Peking Man and has avoided using words such as nationalism, patriotism, and even history education.

A history teacher's reservation about the COC theory may give us a sense of the self-censorship that occurs. In a 2012 interview titled "History Education Should Serve Patriotism but Should Do So in Line with Facts," an unusually bold title by the editor, Li Xiaofeng, a model history teacher in Beijing, begins with the case of Peking Man. Li says he encourages students to think independently rather than blindly believing their textbook. "If you ask them 'Is Peking Man our ancestor?' they will be confused [since the textbook says yes]-how is it possible that someone tells them Peking Man is not our ancestor?" Li then introduces the controversy between the AOC and COC theories. However, he avoids any elaboration on history education and patriotism (Li 2012).

Evidence continues to suggest that even after almost twenty years, supporters of the AOC theory, especially from the natural sciences community, still regard the popularization of the theory as a serious undertaking in the process of enlightening the public. It is not only for scientific purposes but also social purposes. To debunk Peking Man's ancestorship matters more than an act of simply telling the scientific truth. For example, Rao Yi, Dean of the School of Life Science of Beijing University who obtained his Ph.D. in the United States and returned to China after he had established himself as a prominent scientist in the international life science field, told students in his public speech titled "What Type of People Do You Want Yourself To Be?" that "the so-called Peking Man is not the ancestor of any of us who are sitting here today." He went on to delineate the route of human evolution and the migration of $H$. sapiens into China (Rao 2016). Rao is known for his criticism of China's institutional deficiencies in education and research and his skepticism of the guidelines set by the state, especially given the massive government investment in these fields. In the same speech he said he rejected any interpretation of his return to China as a patriotic act. Yuan Shuo, a guide specialized in lithic-era exhibits at the National Museum of China and very popular in the museum's 
interaction with public, had a televised public lecture in 2017. Titled $H$. Sapiens' March, he said "every time I start the tour, I like to ask museum visitors: how does Peking Man relate to modern people? Everybody says he is our ancestor; we are the result of an evolution from him." Unfortunately, Yuan told his audience, there is a reproductive isolation between Peking Man and "us," created by different biological mechanisms of the two species (Yuan 2017).

With regards to anthropologists, only a purely academic purpose has been claimed in response to queries, in particular those from foreign academics and journalists. As Wu Xinzhi put it, "this has nothing to do with nationalism" but is all about evidence, "everything points to continuous evolution in China from $H$. erectus to modern humans," although "they want everything to come from China" is a kind of response from some foreign researchers (Qiu 2016). Sautman argues that the work of Chinese anthropologists "implies that hominids living in what is now China were 'Chinese' and urges that science should reinforce nationalism by showing an ancient Chinese pedigree" (Sautman 2001, p. 103). Acknowledging a nationalist agenda behind the Chinese anthropologists' argument, Schmalzer nonetheless maintains that such an argument is to "defend their discipline's primary data set [i.e., fossils]" and she also believes that "Western ignorance about Chinese fossils" contributes to the nationalist taint of the argument (Schmalzer 2008, p. 270). While both are true, the discourse of anthropologists in recent years does read to be more suggestive of a lithic-age Chinese identity, which is more assertive than defensive. Without directly referring to nationalism or patriotism, it tends to manifest and transmit itself through a narrative of a set of distinctive attributes claimed to have been found in the entire geological epoch telescoping the eras of both $H$. erectus and $H$. sapiens. According to anthropologist Gao Xing in a 2010 IVPP annual research review,

[A]ncient humans in China as well as East Asia had maintained continuity and stability in behaviour and technology throughout the entire Paleolithic and early Neolithic ages, developed a pattern of unique and gradual evolution with a characteristic of inheritance over innovation, and there had not been replacement and interruption. About 800,000 years 
ago, in southern and central China there appeared hand axes and other items similar to the contemporary Western 'Acheulian-technology' type, and about 30,000 years ago in northern China there appeared 'stone blade technology' with characteristics of later European Paleolithic culture, but they existed very isolated and transiently, like short-lived blossoms, and failed to leave any significant influence on native mainstream culture. Based on such evidence, scholars have suggested that the main group of ancient humans during the Pleistocene era in China and even in East Asia had continued to thrive, never experiencing any disruption, that its culture had powerful vigour for life and presented a successive evolutionary relationship; there were a small number of incidental foreign groups who had brought with them 'non-native' culture, but would soon disappear without any trace in the mainstream culture's dominance.

Gao named this Chinese or East Asian evolutionary pattern a "comprehensive behavior model" which "was adaptive to local conditions and harmonious and friendly with the native environment, kept the use of environmental resources to a low level by constant migration and relocation, while reforming and assimilating foreign cultures that had occasionally penetrated [local culture]" (Gao 2010).

If Wu's river-like network hypothesis for $H$. sapiens' global evolution answers the question as to how an independent origin of the Chinese is possible, then Gao's comprehensive behavior model asserts that such an origin is historically inevitable. Superior traits had sustained an archaic hominid group from $H$. erectus to $H$. sapiens over two million years of geological time, showing extraordinary talents and skills in making itself sovereign of the environment while indigenizing foreign influence. But exactly from where did this "powerful vigor" and those fine traits originate? Were they acquired through adaptation to the natural settings, a process in which contingent responses eventually led to structural reconfiguration and intuitive formation, or was it something more inborn? In the context of a strong nationalist tradition that tends to historicize national characteristics, such an evolutionary adaptability and success narrated in a triumphal tone naturally leads to a perception of an immutable and transhistorical Chineseness that arouses awe among its descendants. 
This argument for indigeneity and continuity of the lithic-age experience underlines an already clearly drawn trajectory of the development of prehistoric archaeology and ushers it into the discourse of Chinese civilization (Leibold 2012, pp. 343-348). It facilitates an authoritative Chinese archeological claim in the new millennium for an essentially endogenous, self-perpetuating civilization, a phenomenon among the world's civilizations. In that claim, China is taken for granted as a prehistorical given, and there seems to be no need for restrictive clauses such as "in what is today's China," as the spatial relationship between the past and the present is often so clarified by international scholars when necessary. Such a faithful confidence articulated in academic language had existed even in the early 1940s, as Li Guangming, one of the earliest ethnologists, incorporated paleoanthropological and archaeological findings with ancient historical text to delineate the continuity from Peking Man to the Zhou Dynasty (from the 11th century to the third century BCE): "our race had been native long ago in prehistoric time, and it goes without saying that the later culture was also created by our native ancestors" (Yen 2015, pp. 615-616).

Such a direct and million-year-long link between $H$. erectus and the first dynasties in China has been thematic in some mainstream narratives of the origin and evolution of Chinese civilization. In 2005, The Formation of Chinese Civilization-An Archaeological Perspective, a state-sponsored work by prominent Chinese and Chinese-American archaeologists, was published in both Chinese and English languages. A landmark effort in synthesizing updated research to reinterpret the origin and formative stages of China in a comprehensive and systematic manner," the authors proclaim their mission is to explore "the particular characteristics of the Chinese Paleolithic." Years after genetics rocked the COC theory, however, the book makes no mention of the debate at all

\footnotetext{
${ }^{9}$ For an official assessment of the book by the Institute of Archaeology at the Chinese Academy of Social Sciences, see 朱乃诚, “21世纪初中国文明起源的主要成果、特点和展望” (Zhu Naicheng, Major achievements, characters, and prospects of research of the origin of Chinese civilization in the beginning of the twenty-first century). The book is accessible at http://www. kaogu.cn/cn/xueshuyanjiu/yanjiuxinlun/wenmingtanyuanyanji/2013/1025/36045.html.
} 
in its first chapter entitled "Early Humans in China." Xu Pingfang, the author of the Introduction II of the book and former director of the Institute of Archeology, Chinese Academy of Social Sciences, extends the lineage of Chinese history deep into the mid-Pleistocene era-"This 'pre-Qin' period [the Chinese historical period prior to the late third century B.C. Qin Dynasty], lasting a million or more years, includes the Chinese Paleolithic and Neolithic periods and the Three Dynasties: the Xia, Shang, and Zhou" (Xu 2005, p. 7).

\section{Yuanmou Man and Nationalist Politics}

In this regard, discussions of Yuanmou Man sheds more light on the relationship between the $\mathrm{COC}$ vs. AOC debate and Chinese nationalism, and the relationship can be traced back to parallel the development of the Sino-US engagement, the most important part of China's international relationships. Yuanmou Man (Homo erectus yuanmouensis) refers to two incisors accidently discovered in Yuanmou County, Yunnan Province, during a geological survey for industrial purposes in 1965. In the following decades, archaeologists also discovered pieces of stone artefacts and animal bone showing signs of human work and perhaps the use of fire. The dating of Yuanmou Man has remained controversial but mainstream Chinese anthropologists believe it is 1.7 million years old, therefore standing out as the earliest evidence of China being the home of human evolution at least at the time of its discovery.

Due to the Cultural Revolution's (1966-1976) interruptive impact on cultural and scientific activities, especially in the second half of the 1960s, this discovery was not announced until February 23, 1972. The official account explained the timing as follows: "On the day of Richard Nixon's (the then American President) visit to China, a time of special significance, the Xin Hua News Agency announced the discovery to the world." The correlation between the American President's visit to China (the first time in Sino-US relations) and the announcement of the discovery has been reiterated as "by no means a coincidence" with the exhibit of the Yuanmou Man Museum and popular narratives of the discovery. The timing was determined by the DPCCP, which was 
looking for some big news that would foreground China's international status as the US president arrived in Beijing (Liu 2006). As a matter of fact, decades later, when the Yuanmou Man Museum established its webpage, it opened with a full-screen photo of Chairman Mao shaking hands with Nixon. Later the photo was removed but the lines of explanation remain in the exhibit.

Yuanmou Man continued to support the COC theory. Four years later, in 1976, Chinese scientists held a conference celebrating the one hundred year anniversary of Frederick Engels's The Part Played by Labor in the Transition from Ape to Human. The Xin Hua News Agency announced that "the discovery of 'Yuanmou Man' has pushed the timeline of Chinese human history back more than one million years, identifying Yunnan - a province even beyond the Yangzi River region-as the critical and key area for human origin and evolution, and therefore forcefully challenges the African-origin theory of human evolution and supports the multiregional theory of human origin and its development with convincing evidence. 'Yuanmou Man' has been written into the opening page of the Chinese history textbook as the beginning of human history in China" (Yunnan Provincial Government 2011).

More specific evidence shows that the significance of Yuanmou Man for nationalist education and international propaganda-once again involving the United States-was understood even by Chinese leaders. In October 1988, Song Jian, the then State Counsellor, Chairman of the National Science and Technology Commission, and the party's Politburo member, visited Yunnan Provincial History Museum where some fossils (including a skull believed by some anthropologists belonging to $H$. erectus at the time) found in Yuanmou were displayed. In a letter written to the governor of Yunnan Province and the director of the museum upon his return to Beijing, Song said he was "still in the mood of exhilaration aroused by that Ramapithecus skull." He told them he had just received a copy of National Geographic from America, which was a special issue on the origin of modern humans. Song said he looked for Yuanmou on the map titled "The Peopling of the Earth" in the issue but it wasn't there, although Liujiang Man (sixty-seven thousand years old and from the Paleolithic era) and Peking Man were included. "The author says our ancestors are all immigrants from Africa! 
But if we show them Yuanmou Ramapithecus of more than three million years old, this illustration will be completely cast off!" Song urged for more propaganda efforts to make Yuanmou Man known in the world to "give those undereducated but arrogant Americans a good education." At the end of the letter Song asked to circulate the map in National Geographic (Song 1988).

Song's comments on "undereducated but arrogant" Americans and his hope to "give them a good education" seem a bit too harsh given the fact that the National Geographic article and the map were a global survey of the scientific issue in which China had been already well represented. One may well suspect a nationalist sentiment, instead of a pursuit for scientific accuracy, was behind those critiques.

For scholars of early Chinese history, Song's profound interest in Chinese antiquity and his role in promoting relevant research are an example of state patronage of discussions on national origin. Song is known for his role in the state-sponsored efforts to establish a credible chronology for Xia, Shang, and Zhou, the three earliest Chinese dynasties. Traditional Chinese historical chronology only recognized the year $841 \mathrm{BCE}$ as the beginning of the documented history of China, established in Sima Qian's (the first and most influential figure in Chinese historiography, who lived from the second to the first century, BCE) Shi Ji (The Grand History). This year falls in the middle of the Zhou dynasty. Despite the fact that the existence of Xia and Shang as Chinese states predating Zhou had been generally accepted by historians, the specific dates of Xia, Shang, and the starting date of Zhou had remained undetermined with a very vague estimate of the twenty-third century BCE for Xia. During a state visit to Egypt, where the chronology of ancient civilization is documented with specific dates, Song was impressed and felt an urgency to do the same for Chinese history, a civilization believed to be comparable to Egypt in its antiquity. Song campaigned for an interdisciplinary effort to determine the earliest dates of those dynasties and secured millions of Chinese yuan in funding. Named the Xia, Shang, and Zhou Dynasty Chronology Project, it was completed and preliminary results were produced around 2000, which pushed back the credible time table for Chinese history to some eight hundred years earlier than that determined by Sima Qian (Song 2009). 
Yuanmou Man's ancestorship has also become a battleground between COC and AOC scholars since 2000. In 2005, an international conference held in Yuanmou hosted by the provincial government and under the guidance of COC academics (it was presented by Wu Xinzhi) to celebrate the fortieth anniversary of the discovery of the two teeth. While all the participants including the deputy governor of the province made it clear that Yuanmou Man is undoubtedly the earliest human species and the ancestor of Chinese people, Su Bin presented his paper titled "The Genetic Study of the Origin of Modern East Asian Humans and Their Migration," using DNA data to inform conference participants of the AOC theory. His discordant voice was submerged by "categorical" repudiations from "all experts at the conference" (Yang 2016).

The promotion of Yuanmou Man has been neither purely scientific, nor simply nationalistic, but has also been exploited for economic reasons, similar to Peking Man Museum's collaboration with artists in the creation of the drama Primitive Love of Peking Man and the site of Zhoukoudian as a tourist attraction for the local government. Yuanmou is one of the poorest counties in Yunnan province and the provincial and county governments have proposed several projects to attract not only tourists, but also investors. The very high-profile government project was announced in 2007 with the aim of establishing a "China Yuanmou East Humans Sacrificial Shrine." The project "calls for the global Chinese to participate in the building of a cultural 'human temple' to honor humans of the East." The Chinese Ministry of Commerce, which received the project application, stressed the three main points of the plan as allocating $9750 \mathrm{mu}$ (roughly 1606 acres) of land to build a "massive shrine to honour the ancestor," the shooting of a film about the life of Yuanmou Man, and the composition of a theme song for "all peoples in the world." The ambition was to make the site a "world-class cultural memorial" (The Chinese Ministry of Commerce 2010). However, due to the uncertainty about any returns from investment in such a remote location lacking in even modest infrastructure and accommodation, the project has so far remained on paper. 


\section{"The Chinese Must Have Been the Human Racial Group That Started Evolution Earlier Than the Others"}

Nonetheless, compared with Li Changchun's faith in the prominence of the Chinese in human evolution in the context of the COC vs. AOC debate, Song Jian's enthusiasm for fossils and the chronology project can only be said to be very modest. Li, a member of the CCP Politburo Standing Committee and the Chairman of the Central Spiritual Civilization Steering Committee (both 2002-2012), published an article under his pen name of Yong Chun in the Guangming Daily in 2012. Li's article was a result of his inspection tour to Nihewan (Yangyuan County, Hebei Province), a site of some of the earliest Paleolithic remains found in China. Before Li's visit, Liu Yunshan, the minister of the DPCCP and a member of Politburo, had visited the site and emphasized its importance for nationalist education, believing that the site shows how ancient human evolved in the "East." (Wang, X. 2014. P. 214) With the title "Some Philosophical Thoughts Regarding Human Evolution," Li started with a short explanation of the multiregional and Out-of-Africa theories regarding the origin of humans, and acknowledged the latter as the current mainstream theory. Li claims that he "knows nothing about archaeology nor anthropology," but following Marxist dialectical materialism, Darwin's natural selection, and especially Lamarckian use and disuse theories, he stated his belief in the multiregional theory and strenuously argued for an evolutionarily most advanced status for the Chinese based on his analytical comparisons of the physical characteristics of the world's races. He started with an answer to the question of why the Chinese are less hairy. Early anthropoids had thick and dense hair to keep their naked bodies warm, but as they became more civilized, they came to be aware of the shame of their nudity so they began to use animal furs and tree bark and eventually textiles to cover their bodies. As a result, the function of the body being kept warm by hairs was replaced and led to its gradual loss,

Therefore we can come to the conclusion that the race of the least hairy is the race of the evolutionarily most advanced. Among modern humans, white people are the most hairy, blacks next, followed by brown people, 
yellow people the least, and the Chinese with the least of the least. So, the Chinese must have been the racial group [种群] that started human evolution earlier than the others. Of course, there are some groups in China who are more hairy [than others], that is perhaps the result of racial mixing.

Li then discussed why the Chinese have relatively flatter buttocks. He said that from crawling to upright standing and walking, the bone structure of the human body underwent a directional change of ninety degrees, which altered the direction of force of the central bones to enable the buttock and hip bones to evolve more inwardly rather than bulging outwards. This change enabled the human body to stand upright on two legs, unlike animals that walk on four limbs. Li continued,

So we can come to the conclusion that [among human races] the less protruding the buttock, the earlier upright walking started. Compared with other races, the Chinese buttock is flatter. Therefore, the Chinese must have belonged to the race that started upright walking earlier [than other races].

The third piece of evidence for a more advanced Chinese race is that the length of their forelimbs is shorter than that of other races. Li said that Australopithecus lived in forests and had to hold on to branches and perform jumps so their forelimbs developed to be stronger and longer than their hind legs. As anthropoids came down to the ground and used tools to work, their forelimbs were released from making heavy physical movements resulting in degenerated and shorter forelimbs. His conclusion is that the human race groups whose forelimbs are shorter started evolution earlier than those whose forelimbs are longer. Modern human's forelimbs are in general shorter than their hind legs, but different races exhibit different proportions. Then he ranked racial groups based on a comparison of the lengths of their forelimbs and hind legs, "The lengths of forelimbs and hind legs of black and brown races are the closest, the white race is next, and the yellow race is the least close. Therefore, the Chinese must have been the racial group that abandoned living in trees before the others did." 
The fourth piece of evidence involved the evolution of the olfactory gland. Li said the olfactory gland is an information system that animals use to help them identify groups, look for mates, and define territories by the sense of smell. As evolution developed, humans gradually learned to use language to exchange information, and the primitive function of glands gradually degenerated with the olfactory grand being a typical example,

Therefore, we can come to the conclusion that, as far as the olfactory gland [among different race groups] is concerned, the less remaining, the earlier the evolution. According to some data, among the Han Chinese, only about $4 \%$ of them have armpit sniffing, while the percentage is much higher among Westerners and Africans. So, the degeneration of the olfactory gland among the Chinese started much earlier and progressed further than it did among the other races.

The last piece of evidence is found in the evolution of the stomach and mouth. Li said that using fire weakened the function of the stomach because cooked food is easier to digest. Therefore the stronger the stomach function is, the later the using of fire came and the later the primitive way of eating was abandoned. $\mathrm{Li}$ referred to the Chinese phrase of “eating meat with hairs and blood" (茹毛饮血). Li believed that is why the Chinese cannot eat more raw, cold, and hard food, because their stomach function has degenerated as the result of their more civilized way of eating. He continued to discuss the evolutionary changes that happened to the mouth. Because cooked food was more processed, the number of teeth were reduced and the shape of the mouth became flatter. "Compared with other races, the mouth of the Chinese is flatter. So, the Chinese must have been the race that used fire earlier than the others" (Yong 2012).

Li blamed invasion by foreign imperialist powers and fighting between warlords for the fact that only a few of the earliest human fossils were found in China before 1949, and praised the PRC's significant support in the field. He proclaimed that with more government funding and better coordination, he was fully confident there would be discoveries of fossils of the earliest humans to confirm China's status as an 
"important place in the origin of mankind." The correlation between a strong state and the prominence of human evolution seems so self-evident.

These arguments would read like a satirical essay purportedly written by a public figure unpopular for his utter ignorance and stubborn racism if published elsewhere. However, Li was serious and the newspaper is a very prominent, nationally circulated one targeting intellectuals and cultural elites in the party-state's media empire. Also known for his penchant for poetry, lyric writing, and photography, $\mathrm{Li}$ is regarded as a literatus among his Politburo peers. Clearly, Li privileged the Chinese with a more advanced status with implications of biological, psychological, intellectual, and even moral superiority by his "comparative physical anthropology" and established a global rank accordingly. It does not take much for one-if s/he subscribes these comparisons- to accept the conclusion that the superiority of the Chinese civilization derives from its people's evolutionary advancement.

In fact, precisely the same arguments regarding the relationship between the Chinese and their presumably advanced state in the evolution of hair and olfactory glands had been articulated many decades ago by Chinese intellectuals, as Frank Dikötter observantly noticed, to show the bodily differences between civilization and savagery. Lin Yutang, arguably one of the most popular Chinese writers, and who introduced Chinese culture to the world in the first half of the twentieth century, savored: "A study of the hair and skin of the [Chinese] people also seems to indicate what must be considered results of millennia of civilized indoor living," which answered the question of why Chinese men were much less hairy and Chinese women had absolutely no moustache (Dikötter 2015, p. 90). In an introduction to human races for the general reader, Gu Shoubai, a writer of popular science and especially anthropology, wrote that each race exuded its peculiar odor and that "Africans have a smell of rotten meat one can detect from far away. Browns from America also have a specific odor; they also accuse the whites of having a bad smell” (Dikötter 2015, pp. 93-94).

Chinese AOC scientists also interpret racial differences between East Asians and human groups elsewhere by biological traits formed 
through evolution. In a very recent interview, Li Hui, one of Jin Li's colleagues and director of the Key Laboratory of Modern Anthropology at Fudan University, said that in 2013 Jin Li and his team collaborated with scientists from Harvard University and discovered a gene mutation that at a critical time influenced the evolution of human races. Li said, "the ancestors of our East Asian peoples entered the land of Zhonghua [today's China] from Yunnan [China's southernmost province] and they were the descendants of prehistorical human groups in West Asia. Perhaps in order to adapt to the then hot and humid climate there, a radical mutation happened in their body's EDARI [a type of gene unit]. It is an important gene that controls ectoderm." Li explained that this mutation in EDARI not only led to changes in the shape and color of hair, which later characterize East Asians, but also differentiated East Asians from Europeans in terms of perspiration. The skin tissue (determined by EDARI) of East Asians enables them to radiate body heat more through sweating, therefore East Asians often sweat more than West Asians and Europeans do. Li went further, suggesting that the result of this gene mutation can be used to explain why Westerners like to drink cold or even ice water even in winter, partly because cold water can directly lower their body temperature while East Asians like to drink hot water, regardless of the season, because it helps them to sweat. He said that when East Asians have a fever, as long as it is not very high, they can lie down and cover their body with a heavy quilt to force themselves to sweat-sweating helps lower body temperaturebut this practice doesn't work for Westerners. Li believed that this is the reason for today's "precision treatment," a treatment considering human genetic differences and rejecting a standard or indiscriminate treatment for all types of peoples (Wu 2016).

While Li's explanations cannot answer the question of why many or even most East Asians who grew up in America also drink cold or even ice water in all seasons, and therefore drinking hot or cold drinks might be just a habit formed in different cultures, his interpretations regarding the consequences of gene mutation in hair and skin color as well as skin tissue do not convey any implications of a more advanced evolutionary stage. Rather, they merely describe different evolutionary results determined by natural circumstances, rather than being shaped by the 
species' conscious and goal-oriented efforts. Also, his interpretation does not suggest a relationship between the evolutionary characteristics of the species and its social and cultural traits. More importantly, in the same interview, Li stated, "the Chinese civilization did not begin to appear until 12,000 years ago when the last Ice Age ended, the climate began to turn warm, and agriculture started to develop." Therefore the evolutionary results of explaining racial differences are not read from an apparently cultural and social perspective for the purpose of constructing a unique national character and attesting to its advanced status in the human evolutionary process.

One may blame Li Changchun's utter simplification of the Lamarckian theory of inheritance of acquired characteristics and his ignorance of the development of life science since Lamarck for his astoundingly racial thinking. One may also assume $\mathrm{Li}$ was unaware that similar comparisons had been drawn by Western racists but debunked even before his birth, and his comparisons read like a reincarnation of those dead theories. And lastly, let's assume he might not have intended to use these comparisons to claim for China a superior standing in international affairs. However, one still has to face some critical questions. Why is there such a remarkable resemblance between racial discourses almost a century apart embraced by intellectual and political elites regarding the evidence of and belief in the evolutionary advancement of the Chinese, yet their political ideologies are so distinctively different? Why did $\mathrm{Li}$ adhere so single mindedly and naturally to Lamarckian theory, as he understood and interpreted it, while showing no knowledge at all of other theories, and why did he come so close to those racial theories - without knowing them-in arguing for an evolutionary superiority of a particular present-day race? In this book, I argue that it is precisely this seemingly ignorant, innocent, and naïve racial thinking that characterizes racism with the Chinese characteristics of more independent and native roots.

It is worth pointing out that $\mathrm{Li}$ and Song, as well as Jiang Zeming, belonged to the generation of technocrats from the time of the postMao CCP leadership. They all had a background of education and career experience in technological and industrial fields, having nothing to do with the humanities, social sciences, and sciences related to 
human origins. However, they all showed significant interest in and even commitment to promoting China's status in the studies of the origins of mankind and civilization, and they expressed a firm faith in China being the earliest in these fields. A very intriguing contradiction demands an answer: they are scientific laymen, so why were they so confident about the final result of this ongoing scientific exploration?

This is the kind of attitude Mao held towards debates on the divisibility of elementary particles among international scientists in the mid1960s. Mao, in pursuit of his ideological agenda to justify constant political purges under his regime and within his party, argued that even in socialist society there would be capitalists and class enemies constantly engendered from within and which needed to be periodically identified and eliminated. He could find nothing in Marxist theories to support this argument, therefore he turned to physics where although more elementary particles were being identified, scientists were not sure if such a divisibility would go on indefinitely. Mao jumped into the discussion and claimed his faith in indefinite divisibility and made it clear that it was the scientific foundation for his theory of continued revolution under socialism. His political theory complied with cosmological principles that claimed contradictions and oppositions were universal and permanent in the physical world. It was because of Mao's interest and faith in this indefinite divisibility that the Chinese state lavishly sponsored elementary particle research in the 1960s in the hope of establishing a "Chinese school" of elementary particle physics (Cheng 2006).

Today, the Chinese state's attitude towards the debate between the AOC and COC theories and its supporters bears a resemblance to Mao's treatment of elementary particle physics and the then government's support of the science. Song and Li's confidence in the COC theory and an uncontested antiquity of Chinese civilization reads like Mao proclaiming his faith in the indefinite divisibility of matter to scientists and party leaders: "Do you believe it? Whether or not you believe it, I do anyway" (Cheng 2006, p. 113). What buttresses their confidence in a science to which they are laymen are political and ideological agendas: in the past, it was Mao's political purges under the party-state, and today it is nationalism that legitimates the party-state. Mao 
appealed to a hypothetical scientific theory, and his successors a racial science. Their political power grants to them a discourse hegemony in the sciences.

Peking Man's ancestorship in the post-Mao era was established during the administration of Song, Li, and Jiang, especially given the fact that $\mathrm{Li}$ as a CCP Politburo Standing Committee member was in charge of the party-state's entire propaganda apparatus between 2002 and 2012. After Li, Liu Yunshan, the minister of DPCCP who made inspection tour to Nihewan before Li did, succeeded Li's position in the Politburo Standing Committee. Evidence clearly shows that they were not only informed about the debate between the COC and AOC theories and its nationalist implications, but also used their influence to support the former. As Wang Xitong, the archeologist who was in charge of the Nihewan project, stated that Liu and Li not only made inspection tours to the archeological site in the same year, specifically stressed its value in "seeking roots regarding human evolution in the East" as part of a "state project", but also promised substantial government budget for the site (Wang X. 2014. p. 214). An academic conference was quickly convened following their inspection tours. The link between the debate on human origins and nationalist politics at the highest level is undeniable. Finally, the superiority of the Chinese race has been so explicitly articulated by Li's meticulous attention paid to the would-be evolutionary advancement bestowed on the Chinese, that it is reminiscent of those scientific racial theories of the nineteenth and early twentieth centuries.

\section{"To Expel Homo sapiens, and to Revive Zhonghua!"}

The responses of ordinary people show that in China the subject is not just a popular science lesson but something unequivocally about who "we" are, or a "public discipline" as Wolpoff and Caspari described it. Unlike geneticists and anthropologists, both COC and AOC lay supporters openly politicize the subject. Some find the AOC theory to be a new form of the discredited idea of a Western origin of Chinese 
civilization proposed by European scholars in the nineteenth and early twentieth centuries, or a Western ideological conspiracy that uses unpatriotic and fame-hungry Chinese scientists as agents to deconstruct the foundation of Chinese nationalism. For these people, the AOC theory is a Western theory while the COC is a Chinese theory, almost as if the latter was an indigenous Chinese product. Their opponents dismiss such allegations as patriotic paranoia fostered by a hypernationalism that rests on a presumed confrontation between China and the West.

Similar to multiregionalists outside China, defenders of the COC theory feel offended by the AOC's media publicity. However, their responses are more agitated by nationalism, evident from their distrust of the AOC's Western origin. Lu Guoyao, a senior philologist, deplores that the "molecular biology-based Out-of-Africa theory has prevailed in both 'academic' and 'popular' publications, and even Chinese linguists are now mimicking geneticists." Lu rejects linguists' discussions as an attempt to relegate the dialectal diversity and complexity of China to a singular non-native source and to deny the aboriginality of Chinese civilization. He warns his linguistic colleagues that Western scholarship has been frequently discredited for its tendency of pursuing novelty and creating sensation by making groundless assumptions and far-fetched connections ( $\mathrm{Lu} \mathrm{2012).} \mathrm{In} \mathrm{a} \mathrm{more} \mathrm{sweeping,} \mathrm{book-length} \mathrm{global} \mathrm{his-}$ torical narrative, The Genesis-An Evidential Study of the Chinese Origin of Human Civilization, an amateur but erudite author engages a wide range of academic disciplines to refute the AOC theory as a Western denigration of China accepted by the Chinese due to their lack of cultural confidence. He claims that even $H$. erectus originated in China. China is the cradle of all major world civilizations (Liu 2008).

The response by COC supporters on social media is even more political. Responding to a major report in which both Jin Li and Wu Xinzhi were interviewed, one commentator called Jin a charlatan and asserted that his "research was either funded by Americans or the money was inveigled from the Chinese government. Such an 'achievement' was surely to be published in a famous [foreign] journal to guarantee him fame and money." Two comments followed, "[They] simply just cannot wait to dissolve our nation's cohesive forces," and "Nowadays many discourses are attempting to marginalize our history; they are bidding to 
divide us from all sides, weaken our blood stock, confuse us, insidiously make rumors with a purpose to destroy our cultural and racial durability, and undermine our national unifying forces and confidence. It is a pity that our nation has never been short of such scum" (Hua Ti 2009.1). National History, an avant-garde popular history journal with a liberal tendency, was labeled as a "banana" (meaning it had a yellow skin but was white on the inside, a racialized aphorism used to denote the unpatriotic Chinese people) for a lengthy feature on the subject. The comment asserted that the journal had an agenda of promoting "national nihilism and Western universalist values" (Hua Ti 2009.2).

The most radical defense of the COC theory can be found in a cartoon posted on a BBS (a major online discussion platform) site with the comment "It's time to post it." The cartoon juxtaposes two images on its right side. One shows two naked Peking Man statues (exhibited in a museum) making fire and using a stone as a tool with a Chinese phrase meaning "orthodox" (正统) below the image. The other shows a man capped and dressed in a typical Chinese aristocratic dress style against a background of various scenes of civilized society. Below this image a Chinese phrase "barbarians" (蛮夷) appears. On the left of the cartoon are lines of Chinese characters in a large font: "The great $H$. erectus two million years [ago]; Son of Heaven defends the entrance of his cave; The king would die in the jungles [rather than surrender to a more civilized life?]; No territorial concessions (割地) and no war reparations (赔款); No marriage for peace making (和亲) and no tribute paying (纳贡)." A probable encounter between $H$. erectus (Chinese) and H. sapiens (foreigners) is portrayed as a Stone-Age skirmish between foreign invaders and national defenders. Last, the bottom line (eight large Chinese characters in red) is translated into "Expel H. sapiens and revive zhonghua (China)” (驱除智人 恢复中华), a modified version of a famous Han nationalist anti-Manchu catchphrase (驱除愅虏 恢复中华 Expel the northern barbarians and revive Zhonghua) in the late Qing (Manchu) dynasty (for Hanist anti-Manchu racial nationalism, see Chapter 4). As bizarre as it may seem, the cartoon interprets with an intense feeling the debate between the AOC and COC theories as a transhistorical defense of the Chinese against the foreign at all costs, even a more civilized way of life, a reminder of Chinese anthropologists' argument that had 
Chinese H. sapiens been foreign in origin, then archaeologists would have been able to find more developed tools (Hири 2009). The anonymity of the authorship reveals the existence of highly informed but strongly opinionated racial nationalists in action through social media.

On the other side of the debate, AOC supporters are comfortable with the fact that the Chinese have no prior China-based ancestry, nor an indissoluble relationship with the land. National History reports, "Ever since 1929, we have believed that we have been here for hundreds of thousands years; we have been born here, grown up here and buried here generation after generation. But scientists have recently told us: we actually came from afar" (Huang 2008). Yang Jintao, an editor and popular history author for the History Channel (one of the top web portals), wrote an article about changes in perceptions of "our ancestor" since the late nineteenth century. He told the reader that for quite a while many late Qing and early Republican conservative intellectuals, including Liu Shipei and Zhang Taiyan (two influential anti-Qing scholars who aspired to a great Han nation), embraced a hypothesis of a Western origin for the Chinese created by Terrien de Lacouperie, a nineteenth century French orientalist. According to Lacouperie, the ancestors of the Chinese are the Babylonians. These intellectuals were fascinated by this Western-created theory of a Western origin for the Chinese, a seeming contradiction given their staunch cultural conservatism because it boosted their ethnic and racial confidence: we were descendants of the white race while the ruling Manchu were barbarians. Now, the Chinese believe that their ancestor is independent and native. Leaving the answer to the question of the AOC vs. the COC to further scientific research, Yang nonetheless suggested that changes in the perception of ancestorship reflect a change of national mentality that resulted from different circumstances of Chinese nationalism: "in the late Qing, people built up their [national] confidence through seeking evidence for their Western origin, but today they hope to prove an independent origin of the Chinese" (Yang 2016).

The ideological implication of a fake ancestor and a forged link to the land is obvious for many AOC supporters: in a very devious way, it helps to justify Chinese characteristics in defiance of universal values, as debated by Chinese liberals and conservatives in the 2000s because it 
shows that "we" have been here and unique ever since. However, some of them have gone even further. One internet comment titled "From where did the modern Chinese come? - it is a political question" mentions a Chinese archaeologist's claim made in his speech at the School of Oriental and Asian Studies (SOAS) in London, that the sole purpose of his work in Xinjiang is to prove that the region has been part of China since antiquity. The author continued: "Paradoxically, those patriotic scholars are just the same as those Western racists who they hate. Racists believe the noble whites evolved separately from other races; scholars of this land of miracles [神奇的土地, a sarcastic take on China's presumed greatness] insist that modern Chinese people evolved along a single line of ancestry linking Yuanmou Man to Lantian Man and Peking Man to justify their pride in being Chinese" (Din 2010).

Comments from AOC supporters on those who believe the COC theory are hence contemptuous_- "hoodwinked" and "mentally retarded." In 2014, Wang Sixiang, a popular essayist, responded to the anger of COC supporters on a microblog provoked by a project of The Institute of Zoology of Kunming in Yunnan Province (IZKYP) in 2014 supporting the AOC theory. Wang said that "Our history textbooks not only lie in modern history, but in ancient history as well." Our "ancestors" had been "wiped out by Africans!"-what a terrible fact that has made those "nationalists" so "wretched"! The essay ends sarcasticallythe CCTV now might as well "sing a patriotic song-'Oh, Africa, My Dear Motherland!'” (Wang 2014).

The AOC theory also found supporters in Hong Kong after the former British colony was returned to China in 1997. Pro-democratic political commentator Zhong Zhukang published an essay in 2007 entitled "Genetic Research Rocks the Foundation of Socialism with Chinese Characteristics" in Open Monthly, the most influential political periodical, which survived until 2014. In that article, Zhong said that there were two reasons why mainland scholars ignored the globally accepted AOC theory and adhered instead to the COC theory: one was that the political stake of the research involving ancestors was already high, and the other was that "many mainland scholars are either blind fanatic Han chauvinists or 'great China' nationalists." For the CCP regime, "nationalism was the last straw to clutch at," and they would never admit the 
fact that their "ancestor" came from a continent whose inhabitants had been racially despised in China. Most interestingly, Zhong involved Taiwan in his discussion: he told the reader that genetic research had proven that the ancestors of Taiwan's aboriginal people were Polynesians, therefore China's nationalist myth that included the Taiwanese in its "same ancestor, same blood" nationhood was groundless (Zhong 2007).

\section{A "Homo sinensis"?}

In sum, since China participated in the Human Genome Project (HGP), implications of the debate surrounding Peking Man's ancestorship for nationalism wrapped in scientific jargon have been well understood by various segments of society with ultranationalists and liberal public opinion as the two extremes contesting each other. This divergence also cuts through the Chinese party-state-while its scientific authorities acknowledge the AOC theory as mainstream science and the state benefits from AOC-related scientific achievements, its propaganda and education agencies continue to propagate the COC theory for patriotic education and nationalist mobilization, directed by the top leadership. To promote Peking Man's archaeological site as a base for national patriotic education and commemorate those Chinese anthropologists as patriotic heroes purposefully ignores the internationalist spirit of those foreign scientists who committed themselves to Chinese archaeology and anthropology, as well as China's international prominence in these fields. Davidson Black, the leading anthropologist and chief administrator of the Zhoukoudian site in the early 1930s from whom Peking Man took its name, was so devoted to the job that he ignored the heart condition he was born with and died on site while working on the fossils (Jia 1990, p. 1). Despite the profound gratitude Chinese anthropologists hold for these foreigners, the official narrative of Peking Man, whenever unavoidable, refers to these foreigners' contributions as scientific but rarely internationalist. The word is dodged for its mitigating effect on patriotic sentiment aroused by Peking Man.

The general reader attempting to make sense of the debate may understand it first as a disciplinary one, perhaps reflecting a dichotomy 
between diachronic and synchronic approaches followed by anthropologists and geneticists, respectively. Second, the evidence confirming the survival of the descendants of $H$. erectus throughout the Ice Age has yet to be found. There is also no substantial evidence yet to prove a mixing between African-origin $H$. sapiens and local $H$. erectus or $H$. sapiens in East Asia. It could exist. Third, and this is most important, even if the two types of data - or any type of fossil evidence critically challenging the DNA-based AOC—-should be found, ${ }^{10}$ these ancients cannot be called Chinese (or the ancestor of any particular ethnic or national group). Their habitat was not China (or the fatherland/motherland of any nation state). The vestige of their activity was not Chinese civilization. There exists a fundamental difference between a scientific hypothesis of multiregionalism and its nationalist or racialized interpretation, as Sautman noticed in the works of Wolpoff and Caspari, the leading exponents of the hypothesis that denied that "anything like the 'races' of today existed before the first modern $H$. sapiens." However, multiregionalist scholars in China had not issued similar disclaimers (Sautman 2001, p. 101). Wolpoff and Caspari have since maintained this position, as they stated in their article recently published in China- "All human populations today are equally modern. ... It was not our origins that made us what we are, and it is not our genealogy that makes us unique" (Wolpoff and Caspari 2013, p. 394).

The question of whether and how scientific facts about the human body-living or fossilized, in the form of physical appearance or coded in our DNA — can be used in constructing human social identity as well as narrating the historical transformation of such an identity is not unique to China. Also, a specific science may be used to either challenge or defend an existing perception about such an identity. As Keith Wailoo and others argue, "science does not exist apart from its contexts and uses" and it could be both liberating and confining in its effect on the popular imagination (Wailoo et al. 2012, p. 4). Genetics in China

\footnotetext{
${ }^{10}$ The most recent fossil evidence (forty-seven teeth) suggesting that $H$. sapiens existed in what is today's China (Daoxian, Hunan Province) between one hundred and twenty thousand years and eighty thousand year ago was announced in October 2015, although the relationship between the fossils and Peking Man-age H. erectus remains undetermined (Wu et al. 2015).
} 
challenged Stalinist interpretation of biological evolution in the form of Lysenkoism in the past, and now it undermines racial nationalism. Elsewhere, however, it has a recorded history of being exploited by state-sponsored racism in the twentieth century, and as Wailoo and others have shown, the science is still being manipulated to suit the political agendas of nation states and ethnic groups.

Nadia Abu El-Haj's critical studies of the Israeli discourse of Jewishness is illuminating in this regard. It has been a fundamental assumption of some Israeli historical narratives that contemporary Jews are the direct and pure descendants of an original Hebrew people from ancient Palestine. Genetics in the twentieth century and genome studies in recent decades have been used by this discourse as scientific evidence attesting to that history. Nevertheless, technical difficulties and uncertainties unsolved by the discourse aside, especially regarding how to identify Jews (who is and who is not) under different historical circumstances, Abu El-Haj argues that DNA analysis cannot be directly converted into an identity construct. The barrier between historically formed human consciousness and human bodily facts is epistemological. Abu El-Haj effectively shows how the Israeli discourse has played with genetic data, leaving behind unanswered questions reflecting ambiguity, elusiveness, and an ever-shifting emphasis caused by ignoring such a barrier. Her analysis on the problematic use of genetics in Israeli nationalism therefore provides a comparative perspective as well as a methodological tool in the critique of the use of paleoanthropological science by Chinese nationalism (Abu El-Haj 2012).

The discourse on a pure ancestry, an ancestral home, a natural bond between this ancestor and the environment, and most of all, a narrative that attributes a remarkable lineal continuity to physical, mental, intellectual, and even moral traits unique to this ancestor and its posterity, support fanatical racial nationalisms. The efforts to construct racial uniqueness through finding an $H$. erectus ancestry has led to paleoanthropological hoaxes that catered to nationalism with strong racial implications. The "discovery" of the big-brained, ape-jawed Piltdown Man (named after a hamlet near the site) in England a century ago was celebrated as the long-sought missing link between apes and humans in the chain of evolution, but was debunked in the early 1950s as a 
scientific scandal perpetrated by Charles Dawson, an amateur antiquarian and solicitor. The link was even named Eoanthropus dawsoni_- "Dawson's Dawn Man" - which turned ironically appropriate since the most important human fossils of the Piltdown Man were fake pieces processed or polished by his hands. The fake human fossils heartened the British imperialist pride that had been hurt by the type specimen of Homo heidelbergensis - perceived as the earliest human in Europe and discovered several years earlier (1907) in Germany, the chief rival to British imperialism at the time. The "British Man"—as it was so perceived—rivalled the "German Man" both in age (it was half a million years old) and skull solidity (its bones were thicker), and was widely accepted among elite intellectual and cultural circles. "The Piltdown find would raise not only the reputation of Dawson and Smith Woodward [an anthropologist who joined Dowson's plot], but also of Britain as a key nation in the story of human evolution" (Isabelle et al. 2016).

By comparison, however, Piltdown Man as a scientific hoax that accommodated a nationalist agenda is significantly dwarfed by Japanese Man in many ways. In the early 1980s, Fujimura Shinichi, an amateur archaeologist, excavated many Paleolithic stone artifacts in Miyagi prefecture and subsequently many other places as well. As the dating of the findings kept rolling back from fifty thousand years to five hundred thousand years ago, the biological sketch of an $H$. erectus Japanese Man became clearer with each excavation. This Japanese Man not only distanced Japan from Korea (like in Japan before Shinichi's "findings," the earliest traces of human activity found in Korea were from no earlier than thirty thousand years ago) but also enabled the nation to compete with China, the regional big brother in the field of human evolution. Japanese Man therefore claimed for the nation a prominent place in the history of human evolution. Much more than that, this Japanese Man was portrayed by authoritative scholars and media as "uncommonly intelligent," "capable of building tombs, using colors to differentiate between tools, even performing math," and appeared to have had some sense of spirituality (French 2000). Japanese Man stood to challenge conventional thinking about the intellectual and mental faculty of $H$. erectus for almost two decades in which the nation was plunged into an archeological fever centered on Fujimura, until it was debunked in around 2000 as all of 
these findings were found to be forgeries secretly buried in advance by Fujimura himself. He was called "God's Hand" because of his miraculous series of successes in identifying sites of artifacts. After his "discovery" was debunked, the age of Japanese Man in human evolution was set back to the previously acknowledged date of no more than thirty thousand years ago (Romey 2000).

Compared with Piltdown Man, Japanese Man was much more dubious even at first glance to bear scientific scrutiny. No human fossils were found, only tools and some material culture remains were found, and all the discoveries were made by Fujimura and his team. There was a distinct lack of cross-examination of artefacts by rigorous peer reviews, and contemporary scientific dating and authentication methods. Why was such a charlatan able to fool Japanese academia and society so quickly, so easily, and for so long (fortunately the international anthropological community never took Japanese Man seriously)? Immediately after the debunking, international media pointed out the source of the decades-long national fever of archaeology, "For a nation that has always revelled in its cultural uniqueness, the discoveries were more than heartening; they were almost too good to be true. They meant that Japan was settled more than half a million years ago, which put it on a par in the antiquity scales with its perennial rival, China" (French 2000).

Wai-Ming Ng, a Japan specialist in Hong Kong, provides a more critical analysis on the relationship between the saga of Japanese Man and Japanese nationalism. It is noteworthy that the scientific scandal came at the time when Japanese nationalism, especially its right wing, was on the rise as national confidence was regained after two decades of post-war economic miracles that amazed the world. ${ }^{11} \mathrm{Wu}$ argued that the Fujimura fraud "was indeed a conspiracy involving government agencies, regional governments, the media, and academia... Through textbooks, museums, and designated cultural assets, the officials of the

\footnotetext{
${ }^{11}$ The Fujimura fraud happened roughly at the same time the Japanese government began to rephrase the history of the Japanese invasion of China, which provoked Chinese protests and became an external stimuli for the creation of patriotic songs in China. See Chapter 1. Yasuhiro Nakasone, the Japanese Prime Minister with an attitude of rightist nationalism, visited the Imperial Shrine of Yasukuni in 1985, which was the first such official visit since the end of World War Two. The Chinese government criticized the visit.
} 
central government used Fujimura's findings to enhance national pride and cultural nationalism. Regional governments strove to promote local identity and tourism" ( $\mathrm{Ng} 2010$, p. 104). The last point, that local government exploited the tourist value of Japanese Man, was similar to the one behind the promotion of Peking Man and Yuanmou Man in China, but such a mundane motive only testifies to a new, consumerist form of discourses of race.

By comparison, Piltdown Man is still an anthropological species but Japanese Man is a national ancestor that directly led to the rewriting of the history of the origin of Japanese people and civilization. The difference lies in the fact that the former is just human fossils while all the evidence for the latter showed the creature's intelligence and craft adaptable to the environment and its aesthetic preference and spiritual desire. All of these traits were connected to the characteristics of Japanese civilization. In fact Japanese school history textbooks — especially ones used in the region where Japanese Man was "found" — had included the "discovery" and its interpretation. The absence of human fossils in this case makes the illusive Japanese Man even more intriguing, just as a Japanese puppet show - the man hidden behind the puppet only revealing himself through the pulling of the strings that manipulate the actions of the puppet to gain the audience's admiration. When a direct link between the half a million-year-old ancestor and today's Japanese is established, a scientifically endorsed sense of superiority in human evolution reinforces the myth-based belief in the uniqueness and purity of the people. It is this link that lends racial implications to the nationalist agenda of Japanese Man.

Some Chinese COC scholars were very interested in the discovery of Japanese Man, as it might have supported their theory in their eyes. Huang Weiwen, a paleoanthropologist at the IVPP and an ardent supporter of Yuanmou Man's status as the ancestor of the Chinese people, visited the archaeological sites in Miyagi prefecture before the scandal was debunked. His remarks not only agreed with Fujimura's discoveries but also showed a sign of the possible collaboration between Chinese COC scholars and those Japanese anthropologists in search of an independent East Asian origin of modern humans. As he put it, "the progresses of the Chinese research and the Japanese research are like two 
wheels of a vehicle. We can expect that the chronology [of human evolution] based on the African-origin theory will certainly be changed in near future" ( $\mathrm{Ng} 2010$, p. 91). Huang is a very active researcher and popular science writer. Following a suggestion by Japanese scholars, his book on Peking Man (published in 2005, after Japanese Man was debunked) is titled Peking Original Man (北京原人) instead of the common Peking Man (北京猿人). The pronunciations of 北京原人 and 北京猿人 are precisely the same in the Chinese language, but the former renders the meaning of the "original man of Beijing," thus indicating the status of ancestor and lineage while the latter literarily means "the ape man of Beijing." Interestingly, Japanese Man also literarily meant "Japanese Original Man" in the Japanese language as well (translated into Chinese as 日本原人) when it was believed to be true (Huang 2002).

Although "regarded as illegitimate in our time," as Benjamin Isaac cautions, racism "occurs under different names and in different guises" (Isaac2009, p. 4). However, the political appropriation of the COC theory shows that some classical and prototypical racial thinking persists with little alteration. Among recent discussants of racial nationalism and the myth of a unique ancestor, Maurice Olender reveals "a nostalgia for old Aryanistic themes” in Nouvelle École (New School), a French school of classics, in recent decades, which can also provide a comparative perspective. Despite the notoriety of Nazi propaganda regarding the Aryan race, the Nouvelle École attributes to the origin of Western European civilization a "perfect Aryan genius" of the "Indo-Europeans" since the Neolithic era, manifested in such traits as "abstraction and metaphysics," "reflection," and particularly "a constant tendency to subordinate the natural by integrating it into the political" (Olender 2009, pp. 47, 68). A moral portrait of such a creature is also implied. These echo the Chinese discourse of ancestral genius, implied in the comprehensive behavior model, and praise of ancestral valor and virtue in anthropological and artistic languages. On the national ideological spectrum, many Nouvelle École scholars were leaning towards "various currents of the 'New Right'." In China the most outspoken COC lay supporters are ultra-nationalists for whom defending a purely indigenous origin is a political cause. 
For Olender, the Nouvelle École discourse represented efforts to rehabilitate Homo europaeus (Olender 2009, p. 55), a discredited racial concept that portrayed a presumed superior human stock with a unique social character derived from biological traits. Similar efforts to essentialize and mystify particular human groups can also be found in the discourse about Homo alpinus, a Swiss alpine peasant myth of "a strong, healthy, hardworking, patient, perseverant, good natured but autonomous human type" (Sommer 2012, p. 120). Abu El-Haj also dubs the Israeli construct of a pure-blood and single-ancestor Jewishness Homo israelensis (Abu EI-Haj 2012, pp. 99-108). While these discourses involve a relatively recent time in which human civilizations had begun, the Chinese discourse dates back at least half a million years, sunken deep into pre-human natural history. "Homo sinensis," a term invented by this author to refer to the parallel is therefore more of a legitimate name for the assumed prehistorical and transhistorical human stock with a more biological than cultural connotation.

The nationalist interpretation of the COC theory cannot be dismissed as a wild ramification of an already zealous and insular nationalism embraced only by a handful of hardcore, out of touch conservatives with its influence being inflated by social media. It is a neoracial rhetoric rooted in modern China's nationalist tradition and has collaborated with the racial discourse expressed in the popular music analyzed in the previous chapter. To conclude, Peking Man's ancestorship facilitates the national identity politics in China's rise and a racialized Chineseness as a most cohesive force. Anthony Smith's concise analysis on archaeology's role in legitimating the ethnic nation is a ready tool for a brief final analysis. All concepts in favor of "the nationalist ideal of the distinctive, territorial nation" backed up by archaeology's presentation of the material culture of the past such as uniqueness, essentialism, rootedness, authenticity, indigeneity, or more tangibly, soil, lead to a construction of the "historical homeland" (Smith 2001). The political appropriation of the COC theory has extended the application of these concepts from the ethnic/cultural (measured in thousands of years) to the evolutionary/biological (measured in hundreds of thousands of years). Cultural continuity has been transformed into racial genealogy. A Chinese identity finds its ultimate origin not only in an $H$. erectus ancestry but also 
in an asserted harmony between this hominid and the natural setting. The two fuse into a habitat alien to foreigners from which "motherland/fatherland" (the land is ancestrally "ours") and "Chinese territory since antiquity" acquire absolute legitimacy. In the final analysis, a racial myth of a million-year-old exuberant bioenergy, called the "vigorous vitality and incomparable creativity," as the current Chinese President reiterated, has become a catchphrase that distinguishes the superior Chinese from Others (Xi 2014).

\section{References}

Abu El Haj, N. (2012). The Genealogical Science-The Search for Jewish Origins and the Politics of Epistemology. Chicago: University of Chicago Press.

CCTV (China Central TV) 中国中央电视台. (2000.1). 江泽民主席点燃 中华世纪圣火 [President Jiang Lit the Sacred Fire for China Century]. http://www.cctv.com/specials/2000/news/010104.html. Accessed July 8, 2015.

CCTV (China Central TV) 中国中央电视台. (2000.2). 中华圣火: 从 周口店到世纪坛 [China's Sacred Flame: From Zhoukoudian to China Centennial Monument]. http://www.cctv.com/specials/2000/news/123007. html. Accessed September 8, 2015.

CCTV (China Central TV) 中国中央电视台. (2011). Documentary. 中国 人从哪里来? 第三集 遥远的伊甸园 ['Where Did the Chinese Come From?’ Episode 3, “The Remote Eden”].

Chinese Ministry of Commerce 中国商务部. (2010). 中国元谋东方人类 祭祖坛文化工程项目 [China Yuanmou East Humans Sacrificial Shrine Project]. http://project.mofcom.gov.cn/1800000091_1_31662_0_7.html. Accessed October 2, 2018.

Cheng, Y. (2006). Ideology and Cosmology: Maoist Discussion on Physics and the Cultural Revolution. Modern Asian Studies, 40(1), 109-149.

China Chanjing xinwen bao 中国产经新闻报. (2002, April 12). China Chan Jing News. 为了国家安全看管好我们的遗传密码 [To Protect Our National Security, Safeguard Our Genetic Code]. http://www.china.com. cn/chinese/TEC-c/131537.htm. Accessed September 8, 2015.

Chu, J. Y., et al. (1998). Genetic Relationship of Population in China. Proceedings of the National Academy of Sciences, USA (PNAS), 95(2), 111763-11768. 
CRJ Online 国际在线. (2010). 北京猿人的原始之恋 [Primitive Love of Peking Man]. http://gb.cri.cn/32464/2010/08/27/Zt1325s2971266.htm. Accessed May 1, 2014.

De Groote, I., et al. (2016, August). New Genetic and Morphological Evidence Suggests a Single Hoaxer Created "Piltdown Man". Royal Society Open Science, 3(8), 160328.

Dikötter, F. (2015). The Discourse of Race in Modern China (A Revised and Expanded Version of the Book's 1992 Edition). Oxford: Oxford University Press.

Din，D. 丁丁. (2010). ‘现代中国人从哪里来”是一个政治问题 ['From Where Did the Modern Chinese Come?' Is a Political Question]. http:// book.douban.com/review/3121248/. Accessed May 31, 2014.

French, H. (2000, December 7). Tsukidate Journal; Meet a 'Stone Age' Man So Original, He's a Hoax. New York Times.

Gao, X. 高星. (2010). 中国人祖先起源研究的新进展 [New Developments in the Research on the Origin of Chinese People]. http://www.ivpp.ac.cn/ xwdt/kydt/201004/t20100419_2824934.html. Accessed May 3, 2014.

Green, R. E., et al. (2010). A Draft Sequence of the Neandertal Genome. Science, 328(5979), 710-722.

Harvard School of Public Health. (2003). Conclusion of U.S. Government's Inquiry into HSPH Genetic Research in China. http://archive.sph.harvard. edu/press-releases/archives/2003-releases/press05302003.html. Accessed December 20, 2015.

Hong Kong Wenweipo. (2011). 香港文汇报 “人类文明之火点燃” [“Lighting up fire for human civilizations”]. http://paper.wenweipo.com/2011/07/19/ zt1107190019.htm. Accessed 8 September, 2015.

Horai, S., et al. (1995). Recent African Origin of Modern Humans Revealed by Complete Sequences of Hominoid Mitochondrial DNAs. Proceedings of the National Academic of Sciences, 92(15), 532-536.

$H u a T i$ 话题. (2009.1). 中国人从哪里来? DNA 揭秘华夏族 [From Where Did the Chinese Come? DNA Unravels the Secrets of the Chinese People]. http://comment.news.163.com/news_history_bbs/51UKFRGF00011247. html. Accessed May 29, 2014.

$H u$ a $T i$ 话题. (2009.2). 中国人祖先是非洲人，土著怎样消失? [If the Ancestor of the Chinese Is African, Then How Could Have Natives in China Disappeared?] http://book.163.com/09/1027/13/5MKQ7MFF00923K7T_7.html. Accessed May 29, 2014. 
Huang, A. 黄艾禾 (2008). ‘中国人从哪里来?’ [From where did the Chinese come?] 国家历史 [National History]. October 2008.

Huang, W. 黄慰文. (2002). 北京原人 [Peking Original Man]. Hangzhou: Zhejiang Wenyi Publisher.

Huashengbao 华声报 Huasheng News. (2000, June 15). 中国人是否源于 非洲引发各国学者激烈争论 [Whether Chinese Originated in Africa Has Provoked a Hot Debate Among Scientists]. http://tech.sina.com.cn/ ology/2000-06-15/28179.shtml. Accessed May 31, 2014.

Hири 虎朴. (2009). 是时候了 [It's Time to Post This]. http://bbs.hupu. com/5111254.html. Accessed April 30, 2014 (The web link no longer exists). The image can be viewed in the author article (2017, August). 'Is Peking Man Still Our Ancestor?'-Genetics, Anthropology and Politics of Racial Nationalism in China. The Journal of Asian Studies, 76(3), 593.

Isaac, B., Ziegler J., \& Eliav-Feldon, M. (2009). Introduction. In M. EliavFeldon, B. Isaac, \& J. Ziegler (Eds.), The Origins of Racism in the West (pp. 1-14). Cambridge: Cambridge University Press.

IZKYP 中科院昆明动物所. (2014, August 25). The Institute of Zoology of Kunming in Yunnan Province. 元谋猿人北京猿人不是现代人的 祖先 [Yuanmou Man and Peking Man Are Not Ancestors of Modern Human]. http://yn.people.com.cn/news/yunnan/n/2014/0825/c22849622091885-2.html. Accessed May 29, 2015.

Ji, T. 季谭. (2007). 北京基因组研究所所长杨焕明: 像争夺国土一样争夺 基因资源 [Yang Huanming, Director of HGP Beijing Institute: 'The Battle for Genetic Resource Is as Important as a Battle for Territory']. http://wap. sciencenet.cn/info.aspx?id=193697. Accessed April 12, 2015.

Jia, L. (1990). The Story of Peking Man. Beijing: Foreign Language Press.

Jin, L. (2005). 东亚人群的源流与遗传结构 [The Genetic Structure and Origin of Peoples in East Asia]. 世纪大讲堂 [Century Lectures, a televised public forum for important cultural and scientific discussions led by known scholars]. http://wenku.baidu.com/view/132830ec102de2bd96058818. html. Accessed May 29, 2014.

Jin, L. 金力, \& Chu, J. 储嘉佑 (Eds.). (2006). 中华民族遗传多样性研 究. [Studies of Genetics Diversity of Chinese Nation]. Shanghai: Shanghai Science and Technology Publisher.

Ke, Y., et al. (2001). African Origin of Modern Humans in East Asia: A Tale of 12,000 Y Chromosomes. Science, 292(5519), 1151-1153.

Leibold, J. (2006). Competing Narratives of Racial Unity in Republican China. Modern China: An International Quarterly of History and Social Science, 32, 181-220. 
Leibold, J. (2012). Filling in the Nation: The Spatial and Temporal Trajectory of Pre-historical Archaeology in Twentieth-Century China. In B. Moloughney \& P. Zarrow (Eds.), Transforming History: The Making of a Modern Academic Discipline in Twentieth-Century China (pp. 333-371). Hong Kong: Chinese University of Hong Kong.

$\mathrm{Li}, \quad$ X. 李晓风. (2012). 历史教学应体现爱国主义教育要跟事实 相连接 [History Education Should Serve Patriotic Education But Should Do So in Line with Facts]. http://news.xinhuanet.com/video/2012-09/26/c_123765483.htm. Accessed May 30, 2014.

Lim, M. 林玛利. (2010). 我们流着不同的血液 [We Have Different Blood-Unravel the Myth of the Origin of Ethnic Groups in Taiwan]. Taipei: Qianwei Publisher.

Liu, J. 刘俊升. (2006). 吒访 170 万年前的元谋人 [Visiting Yuanmou Man of 1.7 Million Years Ago]. China West, p. 12. http://mall.cnki.net/magazine/ Article/XBZG200612012.htm. Accessed May 30, 2018.

Liu，B. 流波. (2008). 源一一人类文明中华源流考 [The Genesis-An Evidential Study of Chinese Origin of the Human Civilization]. Changsha: Hunan Renmin Publisher.

Lu, G. 鲁国尧. (2012). 一个语言学人的“观战”与臆说’一一关于中国古 人类学家对基于分子生物学的“出自非洲说’的诘难 [A Linguist’s View on Chinese Paleoanthropologists' Challenge to the Molecular-Based 'Out of Africa' Hypothesis]. 古汉语研究 [Research in Ancient Chinese Language], 97(4).

National Human Genome Research Institute. (2012). What Is the Human Genome Project. https://www.genome.gov/11511417. Accessed December 20, 2015.

National Natural Science Foundation of China Briefing (NNSFCB). 中国国 家自然科学基金会情况交流 119. (2002, February 6). Y 染色体研究揭 示: 现代东亚人起源于非洲 [Research on Y Chromosome Has Revealed That Modern East Asians Originated from Africa]. http://www.nsfc.gov.cn/ nsfc/sysmodels/new_detail.aspx@infoid=3381.htm. Accessed December 20, 2015.

Ng, W.-M. 吴伟明. (2010, October). 日本考古学与民族主义：前期旧 石器捏造事件的意识形态 [Japanese Archaeology and Nationalism: Ideologies Behind the Early Paleolithic Frauds in Japan]. 思与言 [Thought and Words], 48(4), 85-108.

Olender, M. (2009). Race and Erudition. Boston: Harvard University Press. Pääbo, S. (2014). Neanderthal Man: In Search of Lost Genomes. New York: Basic Books. 
People’s Daily. (2005，April 19). 中华民族是否基因安全? 我们的基因 是否外流? [Is Chinese Nation's Gene Safe? Are Our DNA Samples Out Flowing?] http://scitech.people.com.cn/GB/25893/3331825.html. Accessed May 30, 2014.

Peoples Daily. (2008, March 27). 人文奥运展示中华魅力 [A More Cultural Olympics Shows China's Charm]. http://pic.people.com.cn/ GB/31655/7051538.html. Accessed May 20, 2015.

People’s Daily. (2008, August). 奥运圣火在北京传递 [Olympics Flame Torch Is Relayed in Beijing]. http://2008.people.com.cn/GB/113266/128423/ index.html. Accessed May 20, 2015.

Qiu, J. (2016, July 12). How China Is Rewriting the Book on Human Origins. Nature (News Feature). https://www.nature.com/news/how-chinais-rewriting-the-book-on-human-origins-1.20231. Accessed May 30, 2018.

$\mathrm{Qu}$ ，Y. 曲一线 (2013). 初中习题化知识清单(历史) [Junior High School History Key Knowledge (History)]. Beijing: Capital University Publisher. Rabinow, P. (1999). The French DNA. Chicago: University of Chicago Press. Rao, Y. 饶毅. (2016). 你要成为什么样的人? [What Type of People Do You Want Yourself to Be?] https://wenku.baidu.com/view/907ed4b9f01dc281e43af095.html. Accessed May 25, 2018.

Roberts, A. (2009). BBC “The Incredible Human Journey”. Episode 2 (Asia). Romey, K. M. (2000, January-February). God's Hand's Did the Devil's Work. News Brief in Archaeology, 54(1). http://archive.archaeology.org/0101/newsbriefs/godshands.html. Accessed September 26, 2015.

Sautman, B. (2001). Peking Man and the Politics of Paleoanthropological Nationalism in China. The Journal of Asian Studies, 60(1), 95-124.

Schmalzer, S. (2008). The People's Peking Man-Popular Science and Human Identity in 20th Century China. Chicago: University of Chicago Press.

Shen, G., et al. (2009). Age of Zhoukoudian Homo erectus Determined with ${ }^{26} \mathrm{Al} /{ }^{10} \mathrm{Be}$ Burial Dating. Nature, 458, 198-200. https://doi.org/10.1038/ nature 07741.

Smith, A. D. (2001). Authenticity, Antiquity and Archaeology. Nations and Nationalism, 7(4), 441-449.

Sommer, M. 2012. "Do you have Celtic, Jewish or Germanic Roots?" In K. Schramm (Ed.), Identity Politics and the New Genetics: Re/Creating Categories of Difference and Belonging (pp.117-40). New York: Berghahn Books.

Song, J. 宋健. (1988). 致和志强信 (Song Jian's Letter to He Zhiqiang). http://r.cnki.net/knavi/refbook/extend/BWGT_ARBB/R151000013?scode $=\mathrm{R} 15100001300 \mathrm{~A} 000002$. Accessed October 2, 2018. 
Song, J. (2009, October 31). 科技日报“从'星火’计划到'断代工程” [From 'Spark Fire' Project to 'The Chronology of Ancient Chinese History Project,"]. Science and Technology Daily. http://news.ifeng.com/mainland/200908/0831_17_1328036.shtml. Accessed July 26, 2018.

Wailoo, K., Nelson, A., \& Lee, C. (Eds.). (2012). Genetics and Unsettled Past: The Collision of DNA, Race and History. Rutgers: Rutgers University Press.

Wang, S. 王思想. (2014). 我们都是入侵者的后代 [We Are All Descendants of Invaders]. http://t.qq.com/wangxy? $\operatorname{mode}=0 \& \mathrm{id}=40727513$ 4205245\&pi $=9 \&$ time $=1409371707$. Accessed May 29, 2014.

Wang, X. 王希桐. 2014. 泥河湾保护与发展研讨会论文选编. Proceedings of Conference on Preservation and Development of Nihewan Archeological Site. Shijiazhuang: Hebei Kexuejishu Publisher.

Wei， F. 魏芙塘. (1984). 在小学历史教学中重视对学生进行爱国主义 教育 [Engage Students in Patriotic Education in Elementary and Middle Schools History Classes]. Jiangsu Education, 18, 45-47.

Wells, S. (2004). 出非洲记一人类祖先迁徙史 [Journey Out of Africa: The Epic of Human Ancestor's Migration]. Beijing: Dongfang Publisher.

Wen, B., et al. (2004, September 16). Genetic Evidence Supports Demic Diffusion of Han Culture. Nature, 431, 302-305. https://doi.org/10.1038/ nature 02878 .

Wolpoff, M., \& Caspari, R. (1997). Race and Human Evolution. New York: Simon \& Schuster.

Wolpoff, M., \& Caspari, R. (2013). The Origin of Modern East Asians. Acta Anthropologica Sinica, 32(4), 377-410.

Wolpoff, M. H., Thorne, A. G., \& Wu, X. (1984). Modern Homo sapiens Origins: A General Theory of Hominid Evolution Involving the Fossil Evidence from East Asia. In F. H. Smith \& F. Spenser (Eds.), The Origins of Modern Humans, a World Survey of the Fossil Evidence (pp. 411-483). New York: Liss.

Wu, X. 吴新智. (2000, October 30). 北京猿人还是我们的祖先吗 [Is Peking Man Still Our Ancestor?] Guangming Daily.

Wu，X. 吴新智. (2003). 人类起源的多地区进化论 [The Multi-regional Hypothesis of Human Origin]. http://blog.sciencenet.cn/blog-3966217354.html. Accessed October 5, 2016.

Wu，X. 吴新智. (2006). 现代人起源的多地区进化学说在中国的实证 [Evidence of Multiregional Human Evolution Hypothesis from China]. Quatarnary Sciences, 26(5), 702-709. 
Wu，Y. 吴药婷. (2016). 上海科普网 Shanghai Science Net. 中国人的 祖先从何而来? - - 访复旦大学现代人类学教育部重点实验室 主任李辉教授 [From Where Dis the Ancestor of Chinese Come?Interview with Professor Li Hui]. http://2016.shkp.org.cn/grid/department/128/20456275.html. Accessed June 20, 2018.

Wu, L., et al. (2015, October 29). The Earliest Unequivocally Modern Humans in Southern China. Nature, 526, 696-699.

$\mathrm{Xi}, \mathrm{J}$. 习近平. (2014, July 7). 在纪念抗战爆发 77 周年纪念大会上的讲话 [Speech at the Ceremony in Commemoration of 77th Anniversary of the Breaking of the War Against Japanese Invasion]. http://politics.people.com. $\mathrm{cn} / \mathrm{n} / 2014 / 0707 / \mathrm{c} 1024-25247770 . \mathrm{html}$. Accessed May 28.

Xu, P. 徐品芳. (2005). Introduction Part II. In K. Chang \& X. Pingfang (Eds.), The Formation of Chinese Civilization-An Archaeological Perspective. New Heaven: Yale University Press.

Yang, X. 杨雪梅. (2015, April 2). 北京猿人用火有了新证 [New Evidence for Peking Man's Use of Fire]. People's Daily.

Yang, H. 杨红君. (2016, October 29). 中国国土资源作家网 [China Land and Resource Writer Net]. 访问元谋人一一钱方教授情系“元谋人” 25 年田野调查琐记 [Visiting Yuanmou Man-Professor Qian Fang and His Twenty-Five Year Work on 'Yuanmou Man']. http://zj.gtzyb.com/Item/ Show.asp? $\mathrm{m}=1 \& \mathrm{~d}=87619$. Accessed May 20, 2018.

Yang, J. 杨津涛. (2016). 我们是北京猿人的后代吗? [Are We Descendants of Peking Man?] http://view.news.qq.com/original/legacyintouch/d542. html. Accessed July 30, 2018.

Yao, Z. 姚振武. (2010). 人类语言的起源与古代汉语的语言学意义 [The Origin of Human Languages and the Linguistic Significance of Ancient Chinese Language]. Zhongguo Yuwen 《中国语文》, 114(1), 6-8.

Ye, Z. 叶宗元. (2012). 初中历史知识集锦 [Junior High School History Exercise Book]. Nanjing: Nanjing University Publisher.

Yen, H.-P. (2015). Evolutionary Asiacentrism, Peking Man, and the Origins of Sinocentric Ethno-Nationalism. Journal of the History of Biology, 47(4), 585-625.

Yong Chun 永春. (2012, October 29). 关于人类起源的哲学思考 [Some Philosophical Thoughts Regarding Human Evolution]. Guangming Daily. http://epaper.gmw.cn/gmrb/html/2012-10/29/nw.D110000gmrb_ 20121029_1-03.htm. Accessed July 2, 2018.

Yuan Shuo. 袁硕. (2017). 进击的智人 [Homo sapiens in Action]. http://www. sohu.com/a/128043855_627609. Accessed May 30, 2018. 
Yunnan Provincial Government 云南省人民政府. People's Government of Yunnan Province. (2011). 元谋人 [Yuanmou Man]. http://www.yn.gov.cn/ yn_yngk/yn_whzy/201112/t20111231_2738.html. Accessed July 20, 2018. Zhang, L. 张韬岗. (2013). 遗传学界的奠基人谈家桢:一纸万言书推动保 护中国人类基因 [Tan Jiazhen, the Founder of China’s Genetics: A Letter of 10,000 Words for Protection of Chinese Human Gene]. http://www. minmengsh.gov.cn/shmm/n51/n53/u1ai2531.html. Accessed December 20, 2015.

Zhong, Z. 钟祖康. (2007). “基因研究动摇有中国特色的社会主义” [Genetic Research Rocks the Foundation of Socialism with Chinese Characteristics] http://kinghungip.twgg.org/m78/modules/tad_book3/pda. php?tbdsn=46. Accessed July 3, 2018.

Zhongguo gongchandang xinwen. (1997, June 11). 中国共产党新闻 [News of Communist Party of China]. (第一批百个爱国主义教育示范基地名 单) [List of the First one Hundred Bases for Patriotic Education]. http:// cpc.people.com.cn/GB/33843/2598278.html. Accessed May 29, 2014. 